Ege Eğitim Dergisi 2014 (15) 1: 1-44

\title{
Otizmli Çocuğa Sahip Olan Ebeveynlerin Çocuklarının Günlük Yaşam Özellikleri, Günlük Oyun Etkileşimleri, Problem Davranışlar ve İletişim Stillerine İlişkin Görüşleri
}

\author{
Gökhan TÖRET* $\quad$ Selda ÖZDEMIR ${ }^{* *}$ Ömür GÜREL SELIMOĞLU*** \\ Ufuk ÖZKUBAT ${ }^{* * * *}$ \\ $\ddot{O} \mathbf{z}$
}

\begin{abstract}
$\mathrm{Bu}$ araştırmada, otizmli çocuğa sahip olan ebeveynlerin, çocuklarının yer aldığı günlük yaşam rutinlerine yönelik deneyimleri ve çocuklarının sahip olduğu sosyal etkileşim ve iletişim becerileri ile sergiledikleri problem davranışlara ilişkin görüşlerinin belirlenmesi amaçlanmıştır. Araştırmada, otizmli çocuğa sahip olan birincil bakım veren durumundaki 50 ebeveyn ile yarı-yapılandırılmış görüşmeler gerçekleştirilmiştir. Araştırma sonucunda, günlük yaşam özellikleri açısından bazı ebeveynlerin, tüm günlerini çocuklarına adayarak geçirme ve daha az dinlenme süresine sahip olma ile günlük meşguliyetlerinin daha fazla olması biçiminde günlük yaşam özelliklerine sahip oldukları belirlenmiştir. Problem davranışlar ve tekrarlayıcı-yineleyici davranışlar açısından ise ebeveynlerin büyük çoğunluğu, çocuklarının günlük yaşamı olumsuz etkileyici bir problem davranış veya stereo-tipik davranışa sahip olduğunu bildirmişlerdir. İletişim stilleri açısından, ebeveynlerin önemli bir çoğunluğunun, dil ve iletişim özellikleri bakımından, kendileri ve kardeşleri ile iletişim kurarken yoğun olarak jest ve sesleri kullandıkları; en sık olarak çocuklarının akranları ile olan etkileşimlerinde, iletişim yetersizliği sergiledikleri yanıtları elde edilmiştir. Bu araştırmada elde edilen, derinlemesine ebeveyn görüşleri, ilgili nitel araştırmalar doğrultusunda tartışılmış ve gelecekte yapılacak araştırmalara ve uygulamalara yönelik önerilere yer verilmiştir.
\end{abstract}

Anahtar kelimeler: Otizm, ebeveyn görüşleri, günlük yaşam özellikleri, oyun etkileşimi, problem davranışlar, iletişim stilleri.

\footnotetext{
*Arş. Gör., Gazi Üniversitesi, Gazi Eğitim Fakültesi, gokhantoret@hotmail.com

** Doç. Dr., Gazi Üniversitesi, Gazi Eğitim Fakültesi

*** Arş.Gör., Gazi Üniversitesi, Gazi Eğitim Fakültesi

**** Arş.Gör., Gazi Üniversitesi, Gazi Eğitim Fakültesi
} 


\title{
Opinions of Parents of Children with Autism about their Daily Life Characteristics, Play Interactions, and Communication Styles
}

\begin{abstract}
The purpose of this study was to examine opinions of parents of children with autism about their experiences of daily life routines in which their children are involved and about play interactions, communication skills, and problem behaviors of their children. In this study, semi structured interviews were conducted with 50 parents who were the primary caregivers of children with autism. In regard to the daily life characteristics, findings of this study showed that some parents devoted their whole day to their children, they had less time to rest and their daily activities were more frequent. Regarding the problem behaviors and stereotypical-repetitive behaviors, the vast majority of parents reported that their children had some kinds of problem behaviors or stereotypical behaviors which negatively affect their daily lives. In regard to the communication styles, the great majority of the parents stated that their children mostly used gestures and vocalizations while communicating with their siblings and their parents and they displayed impairments in communication with their peers. In depth parent opinions which were examined in this study are discussed in line of qualitative research studies, and suggestions for future research and practice are also included.
\end{abstract}

Key words: Autism, parent opinions, daily routine experiences, play interactions, problem behaviors, communication skills. 
Otizmli Çocuğa Sahip Olan Ebeveynlerin Çocuklarının Günlük Yaşam Özellikleri, Günlük Oyun

Etkileşimleri, Problem Davranışlar ve İletişim Stillerine İlişkin Görüşleri

Giriş

Son yıllarda yetersizlikten etkilenmiş çocuğa sahip olan ebeveynler üzerinde artan sayıda yürütülen araştırmalar, çoğunlukla zihinsel ve gelişimsel yetersizliği olan çocuğa sahip ebeveynler üzerinde yoğunlaşmakla birlikte (Conti-Ramsden, Botting ve Durkin, 2008) otizm tanısı almış çocukların ebeveyn görüşlerine yönelik gelişen ve dar bir alan yazın kapsamında yer alan araştırmalar bulunmaktadır (Hines, Balandin ve Togher, 2012; Stoner ve ark., 2005). Bu araştırmalarda yer alan yetersizlik türlerinden biri olan otizm; erken çocukluk döneminde ortaya çıan, sözel ve sözel olmayan iletişim ve sosyal etkileşim becerilerinde sınırlılıklar ile birlikte takıntılı, yineleyici davranışlar ve ilgi alanlarında sınırlılık ile karakterize edilen bir yaygın gelişimsel bozukluktur (Amerikan Psikiyatri Birliği, 2000). Otizm tanısı almış olan çocuklar üzerinde yürütülen geriye dönük çalışmalar sonucunda ortaya çıkan bulgular, tanı öncesi dönemde normal gelişim gösteren çocuklar ile karşılaştırıldığında otizmli çocukların erken dönem sözel olmayan iletişimsel davranışlardan olan göz kontağı kurma, işaret etme (Osterling ve Dawson, 1994) ve gösterme (Osterling ve Dawson, 1994; Zwaigenbaum Bryson, Rogers, Roberts, Brian ve Szatmari,, 2005) davranışlarının sınırlı olduğunu göstermektedir. Otizmde, tanı öncesinde ortaya çıkan bu gelişimsel seyrin, ebeveynlerin çocuklarının sahip olduğu otizm tanısına ilişkin etiyolojik görüşleri üzerinde etkileri olduğu bulunmuştur (Hebert ve Koulouglioti, 2010). Sosyal iletişimsel davranışların, otizmli çocukların gelişimlerindeki önemi açısından, erken dil edinimi ve sözel olmayan iletişim becerilerinin kullanımı ise, yetişkin yaşa geldiklerinde otizmli bireylerin sosyal yeterlilik ve iletişimlerini yordayan en önemli faktörler olarak görülmektedir (Szatmari, Bryson, Boyle, Streiner ve Duku, 2003). Bunun yanı sıra, sözel olmayan iletişim becerileri gelişiminden başlayarak geniş iletişim gelişimi dağılımı içerisinde dil yeterliliği açısından heterojen bir grup olan (Miniscalco, Franberg, Schachinger-Lorentzon ve Gillberg, 2012) otizm spektrum bozukluğu grubunda bulunan çocuklarda gözlenen iletişim sinırlılıklarının, duygusal davranışsal problemlerle ilişkili olabileceği de belirtilmektedir (Ho, Stephenson ve Carter, 2012). Bu bağlamda, otizm spektrum bozukluğunun karmaşık bir nörogelişimsel bozukluk olduğu dikkate alındığında (Steyaert ve De La Marche, 2008; Patterson, Smith ve Jelen, 2009; Russell ve Norwich, 2012) erken dönemden itibaren gözlenen sosyal iletişim gelişimindeki sıra dışılığa ilişkin otizmin önemli bir özelliği olarak araştırmacıların karşısına çıkmakla birlikte (Mundy ve Burnette, 2005; Roos, Mcduffie, Weismer ve Gernsbacher, 2008), otizmli çocukların en erken dönemlerden itibaren sergiledikleri sosyal ve iletişimsel problemler, ebeveynlerin çocuklarındaki sosyal iletişimsel yetersizlikleri fark etmeleri (Lee, Harrington, Louie ve Newschaffer, 2008) ve gelişimsel farklılıkları algılamaları 
ile birlikte (Boyd, 2002), ebeveynlerin çocuklarının tanılarını anlama gereksinimi de ortaya çıkarmaktadır (Mercer, Creighton, Holden ve Lewis, 2006).

Otizmin, çocukların, erken dönemde bilişsel ve sosyal becerilerin gelişiminde kritik rol oynayan dil ve iletişim (Landa, 2007), sosyal etkileşimi başlatma ve sürdürme (Turnbull, Turnbull ve Wehmeyer, 2007), taklit (Smith and Bryson, 1994) ve oyun becerilerinde (Naber ve ark., 2008) ciddi düzeyde sinurllliklar sergilemeleri biçiminde kendini gösteren otizmin sosyal iletişim gelişimi alanında çoklu yetersizlikler içermesi nedeniyle, diğer yetersizlik türlerine göre (Hastings ve Brown, 2002) otizmin aileler üzerinde daha ileri düzeyde etkileri olduğu bilinmektedir (Meral ve Cavkaytar, 2012). Öte yandan, otizmli çocuklarda, kendini yaralayıcı davranışlar ve öfke nöbetleri gibi yüksek düzeyde duygusal ve davranışsal problemlerinin de gözlendiği bilinmektedir (Dominick, Davis, Lainhart, Tager-Flusberg ve Folstein, 2007). Bununla birlikte, düşük ve yüksek düzey olarak iki kategoriye ayrılan tekrarlayıcı ve yineleyici davranışlar (Turner, 1999), otizmin ayırt edici tanı özelliklerinden biri olmakla birlikte otizmli çocuklarda yüksek sıklıkta ve yoğunlukta görülebilmektedir (Matson, Dempsey ve Fodstad, 2009). Bunun yanı sıra, tekrarlayıcı ve yineleyici davranışlar, otizmli çocukların ebeveynleri ile olan etkileşimlerini, öğrenme ve performansları ile sosyal ilişki geliştirmelerini engelleyebilecek düzeyde ortaya çıkabilmektedir (Wilke ve ark., 2012). Otizmli çocuklarda gözlenen uygun olmayan bu davranışların aileler üzerinde etkilerinden birinin, ebeveynlerin çocuklarının uygun olmayan davranışlar sergilemesine tanıklık etmeleri sonucunda ortaya çıan (Brobst, Clopton ve Hendrick, 2009) ve problem davranışlarını yönetme ve başa çıkmada yaşadıkları stres olduğu tartışılırken (Rao ve Beidel, 2009; Ludlow, Skelly ve Rohleder, 2012), problem davranışların aileler üzerindeki bir diğer etkisinin ise otizmli çocukların kardeşlerinin, problem davranışlardan olumsuz etkilenmeleri olduğu bilinmektedir (Gold, 1993 ;Ross ve Cuskelly, 2006).

Otizm hem aile hem de çocuğu etkilemekle birlikte (Williams, Sears ve Allard, 2004), otizmli bir çocuğa sahip olma, özellikle ebeveynler açısından yaşam boyu süren müdahaleleri beraberinde gerektirmesi anlamina gelmektedir (Hoppe, 2005). Otizmli çocuğa sahip olan ailelerin sosyal yaşantılarını inceleyen boylamsal çalışmalar, otizmin, ailelerin yaşamlarını sürdürmeleri üzerinde ortaya çıkardığı güçlükleri betimlemektedir (Gray, 2002). Bunun yanı sıra, otizmli çocukların sosyal karşllıklılık düzeyinde anlamlı yetersizlikler göstermelerinin ebeveynlerin çocukları ile yanıtlayıcı düzeyde etkileşim kurmalarını güçleştirerek (Leach ve Rocque, 2011) sosyal beceri sınırlılıklarının ebeveynleri ile etkileşimlerini önemli ölçüde etkilemesi (Meirsschaut, Roeyers ve Warreyn, 2011), otizmli çocukların davranışlarının annelerin stres düzeyi ile 
Otizmli Çocuğa Sahip Olan Ebeveynlerin Çocuklarının Günlük Yaşam Özellikleri, Günlük Oyun

Etkileşimleri, Problem Davranışlar ve İletişim Stillerine İlişkin Görüşleri

ilişkili olması (Hastings, 2003), ebeveynlerin otizmli çocukları hakkında endişe duymaları (Hodapp, 1999), otizmli çocuğa sahip olan ebeveynlerin yüksek düzeyde depresyon ve ruh sağlığı problemleri yaşamaları (Daniels ve ark., 2008; Gray, 2002) ve ebeveynlerin stres düzeyinin, çocukları ile olan etkileşim stilleri ile bağlantılı olması (Kasari ve Sigman, 1997) dikkate alındığında otizmli çocukların iletişimsel ve sosyal etkileşimsel davranışlarının aileler üzerindeki etkilerinin belirlenmesinin önemli olduğu düşünülmektedir.

Otizmli çocukların sosyal etkileşimsel ve iletişimsel davranışlar, tekrarlayıcıyineleyici davranışlar ve problem davranışlarının aileler üzerindeki etkilerinin belirlenmesinin gerekli olmasının yanı sıra, ailelerin günlük yaşamlarında otizmli çocukları ile geçirdikleri günlük zaman rutinlerine ilişkin gereksinimlerinin belirlenmesi de önem taşımaktadır. Örneğin, ailelerin gereksinimleri ile ilgili elde edilen görüşlerin incelendiği nitel bir çalışmada, Turnbull ve Ruef (1997), çocuklarının davranışları ile başa çıkmada, ailelerin ev içi rutinlerin oluşturulması ve stres ile ilişkili desteğe gereksinim duyduklarını bildirmiştir. Ebeveynlerin günlük rutinleri içerisindeki çocuklarının davranışları ile ilişkili gereksinimlerinin belirlenmesinin gerekli olduğu düşünülmekle birlikte, ebeveynler ve eğitimcilerin çocuklar açısından en önemli amaçlarından birisi, çocukların ve ailelerinin yaşam kalitelerinin niteliğini en üst düzeye çıkarmaktır. Bu doğrultuda, çocukların ve ailelerinin yaşam niteliklerinin belirlenmesi için bilgi elde edilmesi önemli ve gereklidir (Brewin, Rewnick ve Schormans, 2008). Otizmli çocukların yaşam kalitelerinin niteliğinin belirlenmesi amacıyla, çocukların genel gelişim alanlarındaki var olan gelişimsel düzeylerinin belirlenmesinin yanı sıra, çocukların sahip olduğu uygun ve uygun olmayan davranışlara ilişkin ebeveynlerin görüşlerinin belirlenmesi de önemlidir. Bu doğrultuda, otizm tanısı almış olan çocuklarının bakım verenleri olarak çocuklarına uygun çevre sağlama sorumluluğuna sahip olan ebeveynlerin (Cavkaytar, Batu ve Çetin-Beklan, 2008) çocuklarının durumlarına ilişkin değerlendirmelerinin incelenmesi amacıyla kullanılan bir yöntem ebeveynlerin çocuklarının yetersizlikleri ile ilgili açıklamalarının incelenmesidir (Hines, Balandin ve Togher, 2012). Bu bağlamda, otizmli çocuğa sahip olan ebeveynlerin görüşleri, çocuklarına yönelik eğitimsel müdahalelerin belirlenmesinde rehberlik etmesi açısından önem taşımaktadır. Örneğin, Rodger, Braithwaite ve Keen (2004), erken çocukluk döneminde otizmli çocuğa sahip olan ebeveynlere, çocuklarına yönelik eğitimsel hedef alanlarının belirlenmesine yönelik destek sürecinin betimlenmesi amacıyla yürüttükleri araştırmalarında, erken çocukluk döneminde, iletişim, davranış, oyun ve sosyal etkileşim hedef alanlarının ebeveynler açısından öncelikli alanlar olduğunu belirlemişlerdir. Ebeveyn görüşlerinin eğitim hedeflerinin belirlenmesi açısından önemli olmasının yanı sıra, otizmli çocuklarda gözlenen problem 
davranışların, ebeveynlerin ön yargılar olmaksızın ve içten bakış açıları ile belirlenmesinin yanı sıra bu davranışların ebeveynler üzerinde ortaya çıkardığı endişelerin belirlenmesine de katkı sağladığı düşünülmektedir (Ho ve ark., 2012).

Otizmli çocuğa sahip olan ebeveynlerin görüşlerinin incelenmesi amaciyla yapılan nitel araştırmalar incelendiğinde, ilgili araştırmaların önemli bir bölümünün ebeveynlerin sosyal destek algıları (Ludlow ve ark., 2011; Meral ve Cavkaytar, 2012; Nealy, O'Hare, Powers ve Swick, 2012), tanı ve nedenlerine ilişkin algıları (örn., Alqahtani, 2012; Shaked ve Yoram, 2006; Skinner ve ark., 2001; Hebert-Baltus ve ark., 2010; Mercer ve ark., 2006) sosyal uyumları (Gray, 2002) ve otizmli çocukların eğitim ortamlarında sosyal etkileşim, iletişim ve geçiş becerileri gibi gereksinim duyduğu becerilere ilişkin ebeveyn görüşleri (Hoppe, 2005; Patterson, Smith ve Jelen, 2011) üzerinde odaklandığ1 görülmektedir. Bununla birlikte, küçük yaş grubunda bulunan otizm spektrum bozukluğuna sahip olan çocuklarda gözlenen, DSM-IV (Amerikan Psikiyatri Birliği, 2001) sınıflama sistemi ile belirlenmiş olan semptomların, ebeveyn raporları ile de tutarlılık gösterdiği (Beuker ve ark., 2013) başlıca üç alan olan sosyal etkileşim, iletişim ile stereo-tipik ve problem davranışlar üzerinde yoğunlaştı̆̆ bilinmektedir. Buna karşın, otizmli çocukların sahip olduğu sosyal etkileşimsel davranışlar ile iletişim becerileri ve ebeveynleri ile günlük rutinlerinde oyun etkileşimleri ve sergiledikleri problem davranışlar ile tekrarlayıc1-yineleyici davranışlara ilişkin ebeveyn görüşlerinin incelendiği nitel araştırmaların sayısının sınırlı olduğu görülmektedir (Ho ve ark., 2012). Ayrıca, daha önce tartışıldığ gibi, sosyal etkileşim ve iletişimin otizmde başlıca sinırlılık alanları olduğu (Amerikan Psikiyatri Birliği, 2001) ve bu sinırlılıkların ebeveyn ile çocuk arasındaki etkileşimi olumsuz etkilediği (Spiker, Boyce ve Boyce, 2002) dikkate alındığında, bu araştırmanın birincil bakım verenleri olarak otizmli çocuğa sahip olan ebeveynlerin, günlük yaşam rutinleri, çocuklarının sahip olduğu sosyal etkileşim ve iletişim becerileri, tekrarlayıc1yineleyici davranışlar ve problem davranış tanımlamaları açısından alan yazına bakış sağlayacağı düşünülmektedir. Bu beceri veya davranışların nicelik ve nitelikleri ve bu sosyal-iletişimsel davranışlar ile uygun olmayan davranışların ebeveynler ve diğer aile bireyleri ile yakın çevre üzerindeki yansımalarına ilişkin etkilerine yönelik deneyim ve görüşlerinin belirlenmesinin ilgili alan yazına bakış sağlama ve ileriki nitel araştırmalara yeni problem durumları tanımlama açısından katkı sağlayacağı beklenmektedir. Ayrıca bu araştırmanın, otizmli çocuklara yönelik müdahale uygulamaları ve ebeveynlere yönelik rehberlik hizmetlerinin planlanmasında ebeveyn görüşleri bağlamında özel eğitim alanından çalışan uygulamacılara katkı sağlayacağı düşünülmektedir. Öte yandan, alan yazında ebeveynlerin otizmli çocuklarının almış olduğu tanı 
Otizmli Çocuğa Sahip Olan Ebeveynlerin Çocuklarının Günlük Yaşam Özellikleri, Günlük Oyun

Etkileşimleri, Problem Davranışlar ve İletişim Stillerine İlişkin Görüşleri

(Mercer ve ark., 2006), sergiledikleri problem davranışlar (Ho ve ark., 2012), günlük rutin özellikleri (Nealy ve ark., 2012) ile ilgili görüşlerinin incelendiği araştırmalar bulunmakla birlikte, otizmli çocukların oyun etkileşimleri ve iletişim becerileri ile ilgili ebeveyn görüşlerini inceleyen nitel araştırmaların sayısının sınırlı olduğu görülmektedir. Ayrıca, Türkiye'de bu araştırmada ele alınan temalara ilişkin yetersizlikten etkilenmiş olan çocukların ebeveynlerinin görüşlerinin incelendiği nitel araştırmalar sınırlı da olsa bulunmakla birlikte (Özen, Çolak ve Acar, 2002), otizmli çocuğa sahip olan ebeveynlerin çocuklarında gözledikleri problem davranışlar, günlük yaşam rutinleri, çocukları ile oyun etkileşimleri ve çocuklarının iletişim stillerine ilişkin görüşlerinin birlikte incelendiği nitel bir araştırma bulunmamaktadır. Alan yazında yetersizliğe sahip olan çocuğa sahip ebeveynlerin görüş ve deneyimlerine artan bir ilginin olması nedeniyle (Romski ve ark., 2011), bu çalışmanın, araştırmada belirlenmesi amaçlanan ilgili temalara ilişkin ebeveynlerin görüşlerinin elde edilmesi sonucunda, otizmli çocuğa sahip olan Türk ebeveynlerin görüşlerinin yansıtılması açısından ilgili alan yazına bakış sağlaması beklenmektedir. Bunun yanı sıra ebeveynlerin çocuklarının tanıları ile ilişkili ebeveynlik becerileri ve psikososyal uyumları vb. alanlarda aile merkezli hizmet planlarının geliştirilmesi sürecinde hedef davranışlar hakkında fikir sağlama açısından özel eğitim alanında çalışan uygulamacılara katkı sunması beklenmektedir. Bu doğrultuda, bu araştırmanın amacı, otizmli çocuğa sahip olan ebeveynlerin; çocuklarının yer aldığı günlük yaşam rutinlerine yönelik deneyimleri ile çocuklarının kendileri ile olan oyun etkileşimleri ve iletişim becerileri ile sergiledikleri var olan problem davranışlarına ilişkin görüşlerinin belirlenmesidir.

\section{Yöntem}

\section{Araştırma Modeli}

Otizmli çocuğa sahip olan ebeveynlerin; çocuklarının yer aldığı günlük yaşam rutinlerine yönelik deneyimleri ile çocuklarının kendileri ile olan oyun etkileşimleri ve iletişim becerileri ile sergiledikleri var olan problem davranışlarına ilişkin görüşlerini inceleyen bu araştırma, çocuklarının sahip olduğu otizmin, ebeveynlerin kendileri ve aile yaşamları üzerindeki etkilerini inceleyen büyük bir araştırmanın parçası olarak yürütülmüştür. $\mathrm{Bu}$ araştırmada, otizmli çocuğa sahip olan ebeveynlerin; günlük yaşam rutinlerine yönelik deneyimleri ile çocuklarının sahip olduğu sosyal etkileşim ve iletişim becerileri ile sergiledikleri var olan problem davranışları hakkında ve otizmli çocuklarının sahip olduğu bu özelliklerin, kendileri ve aile yaşamları 
üzerindeki etkilerine yönelik derinlemesine bilgi elde etmek amacıyla, nitel araştırma modellerinden olgu bilim araştırma desenine yer verilmiştir.

\section{Çalışma Grubu}

$\mathrm{Bu}$ araştırmada, otizmli çocuğa sahip olan birincil bakım veren durumundaki 50 ebeveyn ile yarı-yapılandırılmış görüşmeler yürütülmüştür. Bu araştırmada, amaçlı örnekleme yöntemlerinden ölçüt örneklemeye yer verilmiştir. Çalışma grubunda dahil edilen ebeveynlerin çocuklarının ilgili devlet hastaneleri veya üniversitelerin çocuk psikiyatrisi servisleri tarafından otizm tanısı almış olmaları, ebeveynlerin ise a) otizmli çocukları ile yaşam deneyimleri hakkında birincil bilgi kaynağı olmaları ve b) çalışmaya katılmaya gönüllü olmaları araştırmanın çalışma grubunu oluşturmaya yönelik olarak temel seçim ölçütleri olarak belirlenmiştir.

$\mathrm{Bu}$ araştırmanın çalışma grubunu oluşturan ve belirlenen araştırma ölçütlerini karşılayan ebeveynlerden 20'si Isparta il merkezi ve ilçelerinde yaşarken $(n=20)$, 20 'si İstanbul ilinde $(\mathrm{n}=20)$, diğer 10'u ise başkent olan Ankara il merkezinde $(n=20)$ yaşamaktadır. Araştırmacılar için katılımcılara kolay ulaşılması, Ankara ve İstanbul illerinin farklı kültürlerden gelen örneklem grubu özelliğini yansitması, Isparta ilinin ise daha homojen örneklem grubu özelliği göstermesi nedeniyle, belirtilen illerde yaşayan ebeveynler, çalışma grubuna dahil edilmiştir. Tablo 1 ve 2 ' de çalışma grubunda bulunan ebeveynler ile otizmli çocuklarına ilişkin, yaş aralıkları, cinsiyet dağılımı, eğitim düzeyi. vb, sosyodemografik bilgiler gösterilmektedir. 
Otizmli Çocuğa Sahip Olan Ebeveynlerin Çocuklarının Günlük Yaşam Özellikleri, Günlük Oyun

Etkileşimleri, Problem Davranışlar ve İletişim Stillerine İlişkin Görüşleri

Tablo 1. Çalışma Grubunda Bulunan Çocuklara İlişkin Demografik Bilgiler

\begin{tabular}{|c|c|c|c|}
\hline Çocuk Demografik Bilgiler & & $f$ & $\%$ \\
\hline \multirow{3}{*}{ Yaş } & 3-5 & 11 & 22 \\
\hline & $6-8$ & 10 & 20 \\
\hline & $9-12$ & 29 & 58 \\
\hline \multirow[t]{3}{*}{ Kardeşe Sahip Olma } & & 35 & 70 \\
\hline & $\mathrm{K} 1 \mathrm{z}$ & 11 & 22 \\
\hline & Erkek & 39 & 78 \\
\hline \multirow{6}{*}{ Eğitim Ortamı } & $\begin{array}{c}\text { Otistik Çocuklar Eğitim } \\
\text { Merkezi }\end{array}$ & 18 & 36 \\
\hline & Özel Özel Eğitim Merkezi & 10 & 20 \\
\hline & Özel Eğitim Sınıfı & 7 & 14 \\
\hline & Kaynaştırma Ortamı & 5 & 10 \\
\hline & Okul Öncesi Kurum & 5 & 10 \\
\hline & $\begin{array}{l}\text { Özel Özel Eğitim ve } \\
\text { Rehabilitasyon Merkezi }\end{array}$ & 5 & 10 \\
\hline \multirow{5}{*}{$\begin{array}{c}\text { Özel Özel Eğitim Hizmetlerinden } \\
\text { Yararlanma Süresi }\end{array}$} & 1-3 Yil & 16 & 32 \\
\hline & 3-5 Yil & 8 & 16 \\
\hline & $5-7 Y_{11}$ & 15 & 30 \\
\hline & 7-9 Yil & 6 & 12 \\
\hline & 9-11 Yil & 5 & 10 \\
\hline
\end{tabular}

Tablo 1'de görüldüğü gibi, çalışma grubuna dahil olan ebeveynlerin çocuklarının yaşları 3-12 arasında dağılım göstermektedir. Çocukların 11'i kız, $39^{\prime}$ u erkektir. Çocuklar arasından kardeşe sahip olanların sayısı ise $35^{\prime}$ dir. Çalışma grubunda bulunan çocukların, $18^{\prime} \mathrm{i}$ tam zamanlı otistik çocuklar eğitim merkezi, 10'u tam zamanlı özel özel eğitim merkezi, 7'si tam zamanlı özel eğitim sınıfında eğitimlerine devam ederken, 5 'i okul öncesi eğitim kurumunda, $5^{\prime} \mathrm{i}$ ise destek özel eğitim hizmetlerinin sağlanması ise kaynaştırma ortamında eğitimlerine devam etmektedir. 5 çocuk ise özel özel eğitim ve rehabilitasyon merkezlerinde yarı zamanlı olarak destek özel eğitim hizmeti sağlanması ise eğitimlerini sürdürmektedir. Ayrıca çocukların, özel eğitim hizmetlerinden yararlanma sürelerinin 1-11 yıl aralığında olduğu görülmektedir (Tablo 1). Ebeveynlerden elde edilen bilgiler doğrultusunda, çocuklarını sahip olduğu 
otizm tanısı ile ilgili olarak, ilgili devlet hastaneleri ve tıp fakültesi hastaneleri tarafından çocuklarının "otizm" veya "otistik bozukluk" tanısı koyulduğu belirlenmiştir. Bunun yanı sıra, ebeveynler, çocuklarının ciddi düzeyde iletişim ve sosyal etkileşim sınırlılıkları ile sınırlayıcı ve yinelenen ilgi ve davranışlar sergilediklerini ifade etmişlerdir.

Tablo 2. Çalışma Grubunda Bulunan Ebeveynler İlişkin Demografik Bilgileri

\begin{tabular}{cccc}
\hline Ebeveyn Demografik Bilgileri & & $\%$ \\
\hline & Okur Yazar Değil & 2 & 4 \\
& İlköğretim 1. Kademe & 8 & 16 \\
Anne Öğrenim Düzeyi & İlköğretim 2. Kademe & 15 & 30 \\
& Lise & 15 & 30 \\
& Ön Lisans & 2 & 4 \\
& Lisans & 8 & 16 \\
& & & \\
Baba Öğrenim Düzeyi & İlköğretim 1. Kademe & 2 & 4 \\
& İlköğretim 2. Kademe & 12 & 24 \\
& Lise & 16 & 32 \\
& Ön Lisans & 5 & 10 \\
& Lisans & 14 & 28 \\
& Lisans Üstü & 1 & 2 \\
& & & \\
& 1000も< & 12 & 24 \\
& 1000も-2000も & 13 & 26 \\
& 2000も-3000も & 11 & 22 \\
& 3000も-4000も & 4 & 8 \\
& $4000 も-5000 も$ & 6 & 12 \\
& 5000も> & 4 & 8 \\
\hline
\end{tabular}

Tablo 2'de görüldüğgü gibi, çalışma grubunda bulunan ebeveynlerin eğitim düzeyleri, ilköğretim ile lisansüstü eğitim düzeyi arasında dağılım gösterirken, aylık gelirleri 1000 ile 5000 Türk Lirası arasında dağılım göstermektedir (Tablo 2).

\section{Veri Toplama Süreci}


Otizmli Çocuğa Sahip Olan Ebeveynlerin Çocuklarının Günlük Yaşam Özellikleri, Günlük Oyun

Etkileşimleri, Problem Davranışlar ve İletişim Stillerine İlişkin Görüşleri

$\mathrm{Bu}$ araştırmada, ebeveynlerin görüşlerini elde etmek amacıyla yarı yapılandırılmış görüşme tekniği kullanılmıştır. Yarı yapılandırılmış görüşme sürecinde, ebeveynlere yöneltilen görüşme soruları, araştırmacılar tarafından yapılan alan yazın taraması ve otizmli çocuklar ile uygulamacı olarak çalışan araştırmacıların görüşleri doğrultusunda belirlenerek, yarı yapılandırılmış açık uçlu sorulardan oluşan bir görüşme formu oluşturulmuştur. Oluşturulan sorular, açıklık, anlaşılırlık, incelenecek konuyu kapsama ve ailelerin düzeylerine uygunluğu açılarından değerlendirilmesi amacıyla, 4 alan uzmanı tarafından incelenmiştir. Katılımcı seçim ölçütlerine uyan bir ebeveyn ile pilot çalışma niteliğinde bir oturum ön görüşme gerçekleştirildikten sonra alan uzmanlarının incelemeleri ve ön görüşme çalışmasının sonuçlarına bağlı olarak sorulara son şekli verilmiştir. İncelemelerin sonucunda oluşturulan görüşme formu 7 soruyu kapsamıştır. Tablo 3'de görüşme formunda bulunan sorular bulunmaktadir. 
Tablo 3. Yarı Yapılandırılmış Görüşme Soruları

\section{Sorular}

1. Normal gelişim gösteren çocuğa sahip ebeveynler ile kendinizi karşılaştırdığınızda, bir gününüz nasıl geçiyor anlatır misinız ?

2. Bir gününüzü düşündüğünüzde çocuğunuzla karşılıklı oyun oynayarak, konuşarak toplam ne kadar süre geçiriyorsunuz?

3. Çocuğunuzun, sizin günlük yaşantınızı olumsuz etkileyen problem davranışları var mı? Varsa nelerdir ?

4. Çocuğunuz bu problem davranışları sergilediği zaman siz neler yapiyorsunuz?

5. Çocuğunuzun, bu davranışları neden sergilediğini düşünüyorsunuz?

6. Çocuğunuz çok kızdığında ya da hırçınlaştığında çocuğunuzu sakinleştirmek için neler yapıyorsunuz?

7. Çocuğunuz duygularını, düşüncelerini ve ihtiyaçlarını size, kardeşlerine ve akranlarına ifade edebiliyor mu? Nasıl ifade ettiğini anlatır mısınız?

Araştırma sorularının belirlenmesinden sonra araştırmada katılımcı olarak yer alan 50 ebeveyn ile 3 araştırmacı tarafından bire bir görüşmeler yapılmıştır. Yüz yüze gerçekleştirilen bu görüşmelerin öncesinde, katılımcılara yapılması planlanan araştırmanın konusu, amacı ve araştırma planı hakkında yazılı ve sözlü bilgi verilmiştir. Katılımcılara, video/ses kaydı yapılacağı, kaydın sadece araştırmacılar tarafından izleneceği/ dinleneceği ve bu araştırma dışında, araştırma sonuçlarının bilimsel amaçlar dışında kullanılmayacağı, çocukları ve kendilerine ait olan kişisel bilgilerinin araştırmada gizli tutulacağı ve araştırmadan çekilme haklarının saklı olduğu vurgulanarak, araştırmacılar tarafından oluşturulan ebeveyn izin onayı formunu imzalamaları istenmiştir. 
Otizmli Çocuğa Sahip Olan Ebeveynlerin Çocuklarının Günlük Yaşam Özellikleri, Günlük Oyun

Etkileşimleri, Problem Davranışlar ve İletişim Stillerine İlişkin Görüşleri 13

Görüşmelerin tümü katılımcıların uygun gördüğü gün ve saatte, çocuklarının devam ettiği eğitim kurumlarında yapılmıştır. Her bir görüşme 30 ila 60 dakika arasında sürmüş̧ür. Katılımcıların verdiği yanıtlara dayalı olarak gerektiğinde görüşme soruları ile ilişkili ek sorular sorularak daha derinlemesine bilgi toplanmaya çalışılmış ve soruların cevaplanması sırasında, cevaplanan soruya yönelik olarak, bir başka sorunun da cevaplanması durumunda, cevaplanan soru tekrar yöneltilmemiştir. Görüşme sürecinde, ebeveynlerin kendilerini rahatça ifade edebilmeleri için, kurum ortamında görüşme yapılan ebeveynler ile görüşmenin gerçekleştirildiği ortamlar; kamera kaydı ile izlenilmeyen, kurum personeli ve öğrencilerin yoğun olarak kullandıkları ortamlardan uzak ve geçiş trafiğinin olmadığı odalar olarak seçilmiştir. Görüşmeler sürecinde, zaman zaman ebeveynlerin yoğun duygu durumları (öfke, aşırı üzüntü, gözyaşı dökme vb.) yaşadıkları gözlenmiştir. Bu duygu durumlarının yaşandığı durumlarda, ebeveynin görüşmeye rahat bir şekilde devam edebilmesi için görüşmeye kısa zamanlı olarak ara verilmiştir. Görüşmeler esnasında ebeveynlerin, demografik bilgilerine ulaşmak için 16 soru sorulurken, ebeveynlerin bu araştırmanın konusu olan çocuklarının sahip olduğu otizme yönelik ebeveyn algıları, deneyimleri ve çocuklarının sahip olduğu sosyal etkileşimsel-iletişimsel ve davranışsal özelliklerinin ebeveynlerin kendileri ve aile yaşamları üzerindeki etkilerini belirlemeye yönelik olarak 7 soru sorulmuştur (Tablo 3).

\section{Verilerin Analizi}

Araştırmacıların ebeveynler ile yürüttükleri yarı-yapılandırılmış görüşmelerin çözümlemeleri, görüşmelerin elde edildiği ses/video kayıtları üzerlerinde düzeltme yapılmadan, ebeveynler tarafından ifade edilenler duyulduğu şekliyle yazıya dökülerek oluşturulmuştur. Oluşturulan çözümlemelerden, tekrarlı okuma yapılması ve notlar alınması ile katılımcı görüşlerini yansıtan ön temalar oluşturulmuştur. Araştırmacılar, ebeveynler ile yapılan görüşmeleri birbirlerinden bağımsız olarak değerlendirerek temaların uygunluğunu incelemişlerdir. Temalar üzerinde görüş birliğine varılması için, her bir araştırmacı tarafından incelenmesi ve tartışılması sonrasında, her bir araştırmacı tarafından kabul edilmiş ve belirlenmiştir.

Veri analizi süreci boyunca, görüş birliği sağlanarak oluşturulan temalar üzerinden, verilerin betimsel analizleri yürütülmüştür. Betimsel analizler, araştırmacılar tarafından birbirinden bağımsız olarak değerlendirmiş ve veri analizi boyunca araştırma grubunda bulunan araştırmacıların görüş alış verişi sonucunda elde edilen görüş birliği ile güvenirlik sağlanmıştır. 
Araştırmada iç geçerliği sağlamak için; formlarda yer alan sorulara, araştırma verilerine ve yorumlarına ilişkin uzman görüşleri alınmıştır. Ayrıca iç geçerliği sağlamaya yönelik, katılımcıların \% 25'ine (3 öğretmen), verilerin analizinden sonra, ulaşılan sonuçlar ve yapılan yorumlar gösterilerek, katılımcı teyidi sağlanmıştır. $\mathrm{Bu}$ araştırma içerisinde öğretmenlerin görüş bildirdiği cümlelerden doğrudan alıntılar yapılarak araştırmanın aktarılabilirliği (dış geçerliği) sağlanmıştır. İç güvenirliği sağlamak için, bir uzmandan tutarlık incelemesi yapması istenmiştir. İnceleme sonucunda analiz yaklaşımları ve ulaşılan sonuçlarla veriler arasında kurulan ilişkilerin tutarlı olduğu saptanmıştır. Dış güvenirliği sağlamak için ise, araştırmada elde edilen ham veriler ve bu veriler doğrultusunda ulaşılan sonuçlar ve yapılan yorumlar, alan uzmanına onayının alınması bakımından incelemesi için sunulmuş ve alan uzmanının onayı alınmıştır

\section{Bulgular}

Araştırmanın bu bölümünde, otizmli çocuğa sahip olan ebeveynlerin; görüşme formunda yer alan sorulara verdikleri yantların analiz edilmesi sonucunda, günlük yaşam rutinlerine yönelik deneyimleri ile çocuklarının sahip olduğu sosyal etkileşim ve iletişim becerileri ile sergiledikleri var olan problem davranışlarına ilişkin görüşleri bulunmaktadır.

\section{Günlük Yaşam Özellikleri}

"Normal gelişim gösteren çocuğa sahip ebeveynler ile kendinizi karşılaştırdığınızda bir gününüz nasıl geçiyor, anlatır mısınız?" sorusuna verilen yantların analiz edilmesi sonucunda ortaya çıkan ebeveyn görüşleri Tablo 4 'te sunulmuştur. 
Otizmli Çocuğa Sahip Olan Ebeveynlerin Çocuklarının Günlük Yaşam Özellikleri, Günlük Oyun

Etkileșimleri, Problem Davranışlar ve İletișim Stillerine İliškin Görüşleri

Tablo 4: Ebeveynlerin Günlük Yaşam Özellikleri

\begin{tabular}{lcc}
\hline \multicolumn{1}{c}{ Cevaplar } & $N$ & $\%$ \\
\hline Tüm günü çocuğa adama & 18 & 36 \\
$\begin{array}{l}\text { Daha az dinlenme süresine sahip olma ve } \\
\text { günlük meşguliyetlerinin daha fazla olması }\end{array}$ & 18 & 36 \\
$\begin{array}{l}\text { Daha fazla stresli olma, üzüntülü ve kaygı } \\
\text { duygu durumlarını daha yoğun yaşama. }\end{array}$ & 16 & 32 \\
$\begin{array}{l}\text { Daha fazla gözlemci, dikkatli ve kontrolcü } \\
\text { olma }\end{array}$ & 10 & 20 \\
$\begin{array}{l}\text { Daha az nitelikte sosyal yaşantıya sahip } \\
\text { olma ve kendine vakit ayıramama }\end{array}$ & 9 & 18 \\
$\begin{array}{l}\text { Tüm günü evde geçirme } \\
\text { Çocuklarının eğitimi için daha fazla zaman }\end{array}$ & 5 & 12 \\
$\begin{array}{l}\text { ayırma } \\
\text { Daha az şanslı ve rahat olma }\end{array}$ & 6 & 10 \\
$\begin{array}{l}\text { Diğer görüşler (Örn., Farklılık olmaması ve } \\
\text { siradan bir günlük rutine sahip olma }\end{array}$ & 3 & 6 \\
\hline
\end{tabular}

Ebeveynlerin, normal gelişim gösteren çocuğa sahip olan ebeveynler ile kendilerini karşılaştırdıklarında, farklılaşan biçimde günlük yaşam özelliklerine sahip oldukların ifade ettikleri görülmüştür. Normal gelişim gösteren çocuğa sahip olan ebeveynler ile kendilerini karşılaştırdıklarında, bazı ebeveynlerin, tüm günlerini çocuklarına adayarak geçirme ve daha az dinlenme süresine sahip olma ile günlük meşguliyetlerinin daha fazla olması biçiminde günlük yaşam özelliklerine sahip oldukları görülürken (\% 36); bazı ebeveynlerin ise daha fazla stresli olma, üzüntülü ve kaygı duygu durumlarını daha yoğun yaşama biçiminde günlük yaşam özelliğine sahip oldukları görülmektedir (\% 32). Örneğin, bir ebeveyn (E-37), normal gelişim gösteren çocuk ebeveynler ile kendilerini karşılaştırdıklarında bir günlerini değerlendirdiklerinde "...zamanımızın hepsi çocukla geçiyor, ama şu anda vazgeçilmezim olmuş durumda..." yanıtını vererek günlük yaşam özelliğini betimlerken, başka bir 
ebeveyn ise (E-3), " "'... hep ayakta koşturmaca. Normal çocuğu olan arkadaşım oturuyor ben ayakta. Gece uyumuyor, erken kalkıyor dinlenemiyorum. Karşımızda engelli annesi de var sen bana göre daha çok yoruluyorsun diyor...", açıklaması ile günlük yaşam özelliğini betimlemiştir. Diğer bir ebeveyn ise (E-28), " "... yani bir günüm üzüntüyle geçiyor.." günlük yaşam özelliğini yansıtan duygu durumunu ifade ederek ilgili soruyu yantlamıştır.

\section{Günlük Oyun Etkileşimi Süreleri}

"Bir gününüzü düşündüğünüzde çocuğunuzla karşıllklı oyun oynayarak, konuşarak toplam ne kadar süre geçiriyorsunuz ?" sorusuna verilen yanıtların analiz edilmesi sonucunda ortaya çıkan ebeveyn görüşleri Tablo 5 'te sunulmuştur.

Tablo 5: Ebeveynlere Göre Çocukları İle Günlük Oyun Etkileşimlerinin Süresi

\begin{tabular}{lll}
\hline \multicolumn{1}{c}{ Cevaplar } & $N$ & $\%$ \\
\hline 30-60 dakika arası & 16 & 32 \\
30 dakikadan az & 8 & 16 \\
3 saatten fazla & 7 & 14 \\
Hiç & 6 & 12 \\
60 dakikadan fazla & 6 & 12 \\
Diğgr görüşler (örn., 3 saat) & 3 & 6 \\
\hline
\end{tabular}

Tablo 5'te, ebeveynlere göre, çocukları ile sürdürdükleri günlük oyun etkileşimlerinin süresi bakımından, farklı sürelerde çocukları ile oyun etkileşimleri kurdukları görülmektedir. Ebeveynler arasında, çocukları ile günlük oyun etkileşim süresi bakımından, en sık ifade edilen zaman aralığının 30-60 dakika olduğu görülmektedir (\% 32). Bazı ebeveynler, çocukları ile günlük oyun etkileşimlerinin süresinin 30 dakikadan daha az olduğunu bildirirlerken (\% 16), bazı ebeveynlerin diğer ebeveynlerin bildirdiği sürelerden anlamlı olarak daha uzun biçimde 3 saatten fazla sürede çocukları ile günlük oyun etkileşimi kurduklarını belirtmişlerdir (\% 14). Ayrıca, diğer belirtilen günlük oyun etkileşim sürelerine bakıldığında, bazı ebeveynlerin çocuğu ile hiç oyun etkileşimi kurmadığı (\% 12), bazı ebeveynlerin ise 60 dakikadan fazla (\% 
Otizmli Çocuğa Sahip Olan Ebeveynlerin Çocuklarının Günlük Yaşam Özellikleri, Günlük Oyun

Etkileşimleri, Problem Davranışlar ve İletişim Stillerine İlişkin Görüşleri

12), 3 saat (\% 6) ve 2 saat (\% 4) olarak oyun etkileşimi sürelerini betimlediği bulgulanmıştır.

\section{Çocuklarının Kendileri ile Oyun Etkileşimine Katılım Düzeyleri}

"Bu süre içinde çocuğunuzun karşılıkl etkileşiminize katıllmı ne düzeydedir, açıklar mısınız?" sorusuna verilen yanıtların analiz edilmesi sonucunda ortaya çıkan ebeveyn görüşleri Tablo 6'da sunulmuştur.

Tablo 6: Ebeveynlere Göre Çocukları İle Günlük Oyun Etkileşimlerinde Çocuklarının Katılım Düzeyi

\begin{tabular}{lll}
\hline \multicolumn{1}{c}{ Cevaplar } & $N$ & $\%$ \\
\hline $\begin{array}{l}\text { Etkileşimin süre ve nitelik olarak } \\
\text { sinirlı olması }\end{array}$ & 19 & 38 \\
$\begin{array}{l}\text { Etkileşim başlatma ve sürdürme } \\
\text { yeterliliğine sahip olma }\end{array}$ & 11 & 22 \\
$\begin{array}{l}\text { Katılım süresi ve etkileşim } \\
\text { niteliğinin değişkenlik göstermesi }\end{array}$ & 5 & 10 \\
$\begin{array}{l}\text { Oyunlarda/ etkileşimde ebeveyni } \\
\text { yönlendirme }\end{array}$ & 4 & 8 \\
$\begin{array}{l}\text { Oyun etkileşimine katılmama } \\
\begin{array}{l}\text { Oyunlarda/ etkileşimde ebeveynin } \\
\text { yönlendirmesine ihtiyaç duyma }\end{array}\end{array}$ & 3 & 6 \\
$\begin{array}{l}\text { Tek başına oynamayı tercih etme } \\
\text { Diğer görüşler (Örn., Oyun } \\
\text { becerileri yetersizliği) }\end{array}$ & 2 & 4 \\
\hline
\end{tabular}

Tablo 6'da, ebeveynlere göre, çocukları ile sürdürdükleri günlük oyun etkileşimlerinde çocuklarının etkileşime katılımlarının niteliği bakımından, çocuklarının farklı katılım düzeylerinde kendileri ile oyun etkileşimleri kurdukları görülmektedir. Ebeveynlere göre, çocukları ile günlük oyun etkileşim süreçlerinde çoğunlukla çocuklarının kendileri ile olan oyun etkileşimlerinin süre ve nitelik olarak sınırlı olduğu görülürken (\% 32), bazı 
ebeveynlerin ise şaşırtıcı bir şekilde, çocuklarının kendileri ile olan oyun etkileşimlerinde, etkileşimi başlatma ve sürdürme yeterliliğine sahip olduklarını bildirdikleri bulgulanmıştır (\% 22). Örneğin, bir ebeveyn (E-43), çocuğunun kendisi ile günlük oyun etkileşiminde katılım düzeyini ifade ederken, "...etkileşimi sinırlı. Dikkati çabuk dağılıyor...", yanıtını verirken, diğer bir ebeveyn (E-29) ilgili soruya, ".... çok keyif alıyor benimle oyun oynamaktan eğleniyor, babasıyla da aynı şekilde, talimatlar veriyor babasına, babasıyla da oynamaktan zevk alıyor..." yanıtını vermiştir.

\section{Problem Davranışlar ile Stereo-tipik Davranışlar}

"Çocuğunuzun, sizin günlük yaşantınızı olumsuz etkileyen problem davranışları veya tekrarlayıcı veya sınırlı (stereo-tipik) davranışları var mı ?" sorusuna verilen yantların analiz edilmesi sonucunda ortaya çıkan ebeveyn görüşleri Tablo 7' de sunulmuştur.

Tablo 7: Ebeveynlere Göre Çocuklarının Problem Davranış ve Stereotipik Davranışa Sahip Olma Durumu

\begin{tabular}{|c|c|c|}
\hline Cevaplar & $N$ & $\%$ \\
\hline Var & 38 & 76 \\
\hline Yok & 12 & 24 \\
\hline
\end{tabular}

Tablo $7^{\prime}$ de, çalışma grubunda bulunan $(n=50)$, ebeveynlerin büyük çoğunluğunun, çocuklarının günlük yaşamı olumsuz etkileyici bir problem davranış veya stereo-tipik davranışa sahip olduğunu bildirdikleri görülürken (\% 76), belirli sayıda ebeveyn ise çocuklarının günlük yaşamı olumsuz etkileyici herhangi bir problem davranış veya stereo-tipik davranışa sahip olmadığını ifade ettikleri bulgulanmıştır (\% 24).

\section{Gözlenen Problem Davranış / Stereotipik Davranış Türleri}

"Çocuğunuzun, sizin günlük yaşantınız olumsuz etkileyen problem davranışlar ile tekrarlayıcı veya sinırl (stereo-tipik) davranışlar nelerdir ?" sorusuna verilen yanıtların analiz edilmesi sonucunda ortaya çıkan ebeveyn görüşleri Tablo 8' de sunulmuştur 
Otizmli Çocuğa Sahip Olan Ebeveynlerin Çocuklarının Günlük Yaşam Özellikleri, Günlük Oyun

Etkileșimleri, Problem Davranışlar ve İletișim Stillerine İlişkin Görüşleri

Tablo 8: Ebeveynlere Göre Çocuklarının Sergilediği Problem Davranışlar ve Streo-tipik Davranışlar

\begin{tabular}{cll}
\hline Cevaplar & $N$ & $\%$ \\
\hline Anlamsız ses çıkarma & 18 & 36 \\
Başkalarına vurma & 18 & 36 \\
Ağlama nöbetleri & 16 & 32 \\
Öfke nöbetleri & 10 & 20 \\
Başkalarını ısırma & 9 & 18 \\
Nesne takıntısı & 6 & 12 \\
Kendine vurma & 5 & 10 \\
Kendini ısırma & 3 & 6 \\
Eşyaya zarar verme & 3 & 6 \\
$\begin{array}{c}\text { Çekmece/ oda / dolap karıştırma, dağıtma } \\
\text { Zıplama/ çırpınma/ el çırpma }\end{array}$ & 2 & 3 \\
$\begin{array}{c}\text { Diğer görüşler ( örn., Başkalarının } \\
\text { eşyasını/yiyeceğini izinsiz alma) }\end{array}$ & 2 & 3 \\
\hline
\end{tabular}

Tablo 8 incelendiğinde, çalışma grubunda bulunan $(n=50)$ ebeveynlere göre çocuklarının günlük yaşamı olumsuz etkileyen geniş yelpaze içinde ve farklı türde problem davranış veya stereo-tipik davranışları bulunmaktadır. Ebeveynler arasında en sık olarak, çocuklarının anlamsız ses çıkarma biçiminde vokal türde stereo-tipik davranışa sahip olduğu bildirilirken (\% 36), en sık bildirilen bu stereo-tipik davranışı, başkalarına vurma (\% 36) ve ağlama nöbetlerinin (\% 32) izlediği görülmektedir (Tablo 12). Örneğin, bir ebeveyn (E18), çocuğunun sahip olduğu problem davranış veya stereo-tipik davranışı tanımlarken " "...anlamsız ses çıkarma, çimdikleme, başkasına vurma...", yanıtını verirken, diğer bir ebeveyn (A-40), " "...Anlamsız ses çıkarma, başkasına vurma..." olarak ilgili sorunun yanıtını vermiştir. 
Gözlenen Problem Davranış / Stereotipik Davranışların Sergilendiği Ortam ve Durumlar

"Bu problem davranışlar veya tekrarlayıcl-sinırl davranışlar (stereo-tipik) hangi durumlarda, ortamlarda sergiliyor?" sorusuna verilen yantların analiz edilmesi sonucunda ortaya çıan ebeveyn görüşleri Tablo 9 'da sunulmuştur

Tablo 9: Ebeveynlere Göre Problem Davranışlar ile Stereo-tipik Davranışların Sergilenme Ortamları ve Durumları

\begin{tabular}{lll}
\hline \multicolumn{1}{c}{ Cevaplar } & $N$ & $\%$ \\
\hline Ortam fak etmiyor & 13 & 26 \\
Evde & 13 & 26 \\
$\begin{array}{l}\text { Bir şey istediğinde/ isteği yerine } \\
\text { getirilmediğinde }\end{array}$ & 6 & 12 \\
Okulda & 3 & 6 \\
$\begin{array}{l}\text { Sıkıldığında } \\
\text { Ortam/ rutin değiştiğinde }\end{array}$ & 3 & 6 \\
$\begin{array}{l}\text { Kendisinden başka çocukları/ } \\
\text { bebekleri gördüğünde }\end{array}$ & 3 & 4 \\
$\begin{array}{l}\text { Gergin ortamlarda/ gürültülü } \\
\text { ortamlarda }\end{array}$ & 2 & 4 \\
$\begin{array}{l}\text { Diğer görüşler (örn., kendisine } \\
\text { kızıldığında) }\end{array}$ & 2 & 4 \\
\hline
\end{tabular}

Tablo 9'a bakıldığında, çalışma grubunda bulunan $(n=50)$ ebeveynler arasında, çocuklarının problem davranışlar veya stereo-tipik davranışları ortam fark etmeksizin sergiledikleri, en sık ifade edilen yanıtlar arasında olduğu görülürken (\% 26), ebeveynlere göre çocuklarının problem davranışları veya stereo-tipik davranışları ev ortamında sergilediği diğer en sık ifade edilen yanıtlar arasında olduğu bulgulanmıştır (\%26). Belirli sayıda ebeveyn ise çocuklarının problem davranış veya stere-tipik davranışları, çocuklarının bir 
Otizmli Çocuğa Sahip Olan Ebeveynlerin Çocuklarının Günlük Yaşam Özellikleri, Günlük Oyun

Etkileşimleri, Problem Davranışlar ve İletişim Stillerine İlişkin Görüşleri 21

şey istemeleri durumlarında veya isteklerinin yerine getirilmediği durumlarda ortaya çıktığını bildirmişlerdir ( $\% 12$ ).

\section{Gözlenen Problem Davranış / Stereotipik Davranışların Hangi Kişilerin Varlığında Sergilenme Durumları}

"Bu problem davranış veya tekrarlayıcl-sınırlı davranışlar (stereo-tipik) kimlerin varlığında ortaya çıkıyor?", sorusuna verilen yanıtların analiz edilmesi sonucunda ortaya çıkan ebeveyn görüşleri Tablo 10' da sunulmuştur.

Tablo 10: Ebeveynlere Göre Problem Davranışlar ile Stereo-tipik Davranışların Kişilerin Varlığında Sergilenme Durumları

\begin{tabular}{lcc}
\hline \multicolumn{1}{c}{ Cevaplar } & $N$ & $\%$ \\
\hline Fark etmiyor & 18 & 36 \\
Anne & 6 & 12 \\
Kardeş & 4 & 8 \\
Yabancı kişiler & 4 & 8 \\
$\begin{array}{l}\text { Başka çocukların/ bebeklerin } \\
\text { yanında } \\
\text { Diğer görüşler (örn., baba) }\end{array}$ & 2 & 4 \\
\hline
\end{tabular}

Tablo 10 incelendiğinde, çalışma grubunda bulunan $(n=50)$ ebeveynler arasında, çocuklarının problem davranışlar veya stereo-tipik davranışları herhangi bir kişinin varlığı fark etmeksizin sergiledikleri, en sık ifade edilen yanıt olduğu görülmüştür (\% 36). Belirli sayıda ebeveyn ise çocuklarının problem davranış veya stere-tipik davranışları, anneleri ile birlikteyken ortaya çıktığını bildirmişlerdir ( $\% 12$ ).

\section{Problem Davranışların Sergilenmesi Durumunda Ebeveyn Tepkileri}

"Çocuğunuz bu problem davranışları sergilediğinde siz ne yapıyorsunuz?" sorusuna verilen yanıtların analiz edilmesi sonucunda ortaya çıan ebeveyn görüşleri Tablo 11'de sunulmuştur. 


\section{Tablo 11: Problem Davranışların Sergilenmesi Durumunda Ebeveyn} Tepkileri

\begin{tabular}{llc}
\hline \multicolumn{1}{c}{ Cevaplar } & $N$ & $\%$ \\
\hline Sözel olarak uyarma & 9 & 18 \\
$\begin{array}{l}\text { Gezmeye çıkarma, bulunduğu } \\
\text { ortamdan farklı ortama geçirme }\end{array}$ & 9 & 18 \\
$\begin{array}{l}\text { Görmezden gelme } \\
\text { Dikkatini başka bir nesne veya } \\
\text { olaya yöneltme }\end{array}$ & 8 & 16 \\
$\begin{array}{l}\text { Sarılma, tutma,durdurma, } \\
\text { sakinleştirme }\end{array}$ & 7 & 14 \\
$\begin{array}{l}\text { Tedbir alma (Davranışı önceden } \\
\text { önlemek için ortam düzenleme) }\end{array}$ & 6 & 12 \\
$\begin{array}{l}\text { Kızma, azarlama } \\
\begin{array}{l}\text { Davranışa hedef olan kişinin } \\
\text { güvenliğini sağlama }\end{array}\end{array}$ & 6 & 12 \\
$\begin{array}{l}\text { Müdahale etmeme } \\
\text { Diğer görüşler (örn., vurma) }\end{array}$ & 4 & 8 \\
\hline
\end{tabular}

Tablo 11'de görüldüğü gibi, çalışma grubunda bulunan $(n=50)$ ebeveynler, çocukları problem davranış sergilemeleri durumunda, farklılaşan biçimde tepkiler verdiklerini bildirmektedirler. Çocukları problem davranış sergilediğinde, ebeveynlerin en sık olarak verdikleri tepkiler arasında sözel olarak uyarıda bulunmaları olduğu görülürken (\% 18), sonrasında en sık bildirilen diğer tepkilerin ise gezmeye çıkarma, bulunduğu ortamdan farklı ortama geçirme (\% 18), görmezden gelme (\% 16), dikkatini başka bir nesne veya olaya yöneltme ( $\% 16)$, sarılma, tutma, durdurma, sakinleştirme (\% 14) olduğu görülmektedir. Örneğin, bir ebeveyn (E-1), çocuğunun problem davranış sergilemesi durumunda " ".. hayır yapma diyorum, kardeş o diyorum, bebek o diyorum ...", yanıtını verirken, diğer bir ebeveyn ise (E-42), " "... gezmeye 
Otizmli Çocuğa Sahip Olan Ebeveynlerin Çocuklarının Günlük Yaşam Özellikleri, Günlük Oyun

Etkileşimleri, Problem Davranışlar ve İletişim Stillerine İlişkin Görüşleri 23

götürüyorum, dikkatini farklı alanlara çekmeye çalı̧̧ıyorum. ..." açıklamasında bulunarak ilgili soruya yanıt vermiştir.

\section{Aşırı Düzeyde Hırçınlaşma veya Öfkelenme Durumlarında Ebeveyn Tepkileri}

"Çocuğunuz çok öfkelendiğinde ya da hırçınlaştığında çocuğunuzu sakinleştirmek için neler yapıyorsunuz?" sorusuna verilen yanitların analiz edilmesi sonucunda ortaya çıkan ebeveyn görüşleri Tablo 12' de sunulmuştur

Tablo 12: Çocuklarının Aşırı Düzeyde Hırçınlaşması veya Öfkelenmesi Durumunda Ebeveyn Tepkileri

\begin{tabular}{lll}
\hline \multicolumn{1}{c}{ Cevaplar } & $N$ & $\%$ \\
\hline $\begin{array}{l}\text { Sarılma, kucağa alma,durdurma, } \\
\text { okşama }\end{array}$ & 20 & 40 \\
$\begin{array}{l}\text { Sözel olarak uyarma } \\
\begin{array}{l}\text { Dikkatini başka nesne veya olaya } \\
\text { yöneltme }\end{array}\end{array}$ & 11 & 22 \\
$\begin{array}{l}\text { Gezmeye çıkarma, farklı ortama } \\
\text { çkarma }\end{array}$ & 9 & 10 \\
$\begin{array}{l}\text { Görmezden gelme } \\
\begin{array}{l}\text { Hoşuna giden nesne, etkinlik } \\
\text { sağlama }\end{array}\end{array}$ & 9 & 18 \\
$\begin{array}{l}\text { Diğer görüşler (örn., dışarı atma, } \\
\text { başka bir ortama kapatma) }\end{array}$ & 2 & 10 \\
\hline
\end{tabular}

Tablo 12'de, çalışma grubunda bulunan $(n=50)$ ebeveynler, çocukları çok öfkelendiğinde ya da hırçınlaştığında çocuklarını sakinleştirmek için en sık olarak verdikleri tepkilerin, çocuklarını sarılma kucağa alma, durdurma ve okşama olduğu görülürken (\% 40), sonrasında bildirilen diğer tepkilerin ise sözel olarak uyarma (\% 22) ve dikkatini başka nesne veya olaya yöneltme (\% 20) olduğu görülmektedir. Örneğin, bir ebeveyn (E-19), çocuğunun çok öfkelenmesi veya hırçınlaşması durumunda "... sakinleştirmek için dur derim 
yapma, kucaklamaya çalışırım..." yanıtını verirken, diğer bir ebeveyn ise (E-19), ".... ben genelde kucağıma alırım, seversem öpersem sakinleşir..." yanitını vermiştir.

\section{Problem Davranışların Ortaya Çıkma Nedenleri}

" Çocuğunuzun, bu davranışları neden sergilediğini düşünüyorsunuz? " sorusuna verilen yanıtların analiz edilmesi sonucunda ortaya çıan ebeveyn görüşleri Tablo $13^{\prime}$ te sunulmuştur

Tablo 13 : Ebeveynlere Göre Çocuklarının Problem Davranış Sergileme Nedenleri

\begin{tabular}{lll}
\hline \multicolumn{1}{c}{ Cevaplar } & $N$ & $\%$ \\
\hline İlgi elde etme & 13 & 26 \\
İlgiden-görevden kaçma & 7 & 14 \\
Nesne, yiyecek elde etme & 6 & 12 \\
Bilinmezlik & 5 & 10 \\
$\begin{array}{l}\text { Dürtüsel/Kendini uyarma amaçlı } \\
\text { veya otizm kaynaklı }\end{array}$ & 3 & 6 \\
$\begin{array}{l}\text { Diğer görüşler (örn., iletişim } \\
\text { becerilerine sahip olmama) }\end{array}$ & 1 & 2 \\
\hline
\end{tabular}

Tablo 13 incelendiğinde, çalışma grubunda bulunan $(n=50)$ ebeveynlerin, çocuklarının problem davranış sergileme nedeni olarak ifade ettikleri en sık yanıtın ilgi elde etme olduğu dikkat çekicidir ( \%26). Bunun yanı sıra, belirli sayıda ebeveynin çocuğunun problem davranışı sergileme nedeni olarak ilgi veya görevden kaçınma yanıtını verdikleri (\% 14) bulgulanmaktadır. Örneğin, bir ebeveyne (E-1), çocuğunun neden problem davranış sergilediği sorulması üzerine "....kıskanıyor...", yanıtını verirken, diğer bir ebeveyn ise (E-5), "..... oradakilerden rahatsızlık duyduğu için yapıyor....." yanıtını vermiştir. 
Otizmli Çocuğa Sahip Olan Ebeveynlerin Çocuklarının Günlük Yaşam Özellikleri, Günlük Oyun

Etkileşimleri, Problem Davranışlar ve İletişim Stillerine İlişkin Görüşleri

İletişim Becerileri

\section{Ebeveynler ile İletişim Stilleri}

"Çocuğunuzun duygularmı, düşüncelerini ve ihtiyaçlarmı size nasıl ifade ettiğini anlatır misiniz?" sorusuna verilen yanitların analiz edilmesi sonucunda ortaya çıkan ebeveyn görüşleri Tablo 14'te sunulmuştur.

Tablo 14: Ebeveynlere Göre Çocuklarının Ebeveynlerine Yönelik İletişim Stilleri

\begin{tabular}{lcc}
\hline \multicolumn{1}{c}{ Cevaplar } & $N$ & $\%$ \\
\hline Jest ve sesler ile iletişim kurma & 48 & 96 \\
Tek sözcük ile iletişim kurma & 19 & 38 \\
Cümle kullanarak sözel iletişim kurma & 12 & 24 \\
İletişim Yetersizliği & 1 & 2 \\
\hline
\end{tabular}

Tablo 14'te, çalışma grubunda bulunan $(n=50)$ ebeveynlerin önemli bir çoğunluğunun, çocuklarının kendilerine yönelttikleri dil ve iletişim özellikleri bakımından, kendileri ile iletişim kurarken yoğun olarak jest ve sesleri kullandıkları yanıtını verdikleri görülmektedir (\%96). Örneğin, bir ebeveyn (E38), ilgili soruya yanıt olarak çocuğunun kendisine yönelttiği iletişim stilini tanımlarken "... göstererek ve işaret ederek ifade ediyor..." yanıtı verirken, başka bir ebeveyn ise (E-23), "..elimden tutar suyun yanına götürüp elimi oraya doğru uzatır.." açıklaması ile çocuğunun kendisine yönelttiği iletişim stilini betimlemiştir. Ebeveynlerin, çocuklarının kendileri ile olan etkileşimlerinde, çocuklarının iletişim stillerini betimlemeye yönelik diğer verdikleri yantlara bakıldığında, çocuklarının kendileri ile tek sözcük ile (\% 38) veya cümle kullanarak sözel iletişim kurduğunu (\% 24) ifade etmişlerdir. Bunun yanı sıra, bir ebeveyn çocuğunun kendisi ile iletişimin tamamen yetersiz olduğunu betimleyerek hiç iletişim kurmadığını ifade etmiştir. 


\section{Kardeşler ile İletişim Stilleri}

"Çоси ğunuzun duygularını, düşüncelerini ve ihtiyaçlarını kardeşine / kardeşlerine nasıl ifade ettiğini anlatır mısınız?" sorusuna verilen yanıtların analiz edilmesi sonucunda ortaya çıan ebeveyn görüşleri Tablo $15^{\prime}$ te sunulmuştur.

Tablo 15: Ebeveynlere Göre Çocuklarının Kardeş / Kardeşlerine Yönelik İletişim Stilleri

\begin{tabular}{lcc}
\hline \multicolumn{1}{c}{ Cevaplar } & $N$ & $\%$ \\
\hline Jest ve sesler ile iletişim kurma & 27 & 54 \\
Tek sözcük ile iletişim kurma & 16 & 32 \\
Cümle kullanarak sözel iletişim kurma & 9 & 18 \\
İletişim yetersizliği & 5 & 10 \\
\hline
\end{tabular}

Tablo 15'e bakıldığında, çalışma grubunda bulunan $(n=50)$ ebeveynler arasından, kardeşi olduğunu bildiren ebeveynlerin $(n=35)$ en sık olarak, çocuklarının kardeşi / kardeşlerine yönelttikleri dil ve iletişim özellikleri bakımından, ebeveynlerine yönelttikleri iletişim stiline benzer olarak, kardeşi / kardeşleri ile iletişim kurarken yoğun olarak jest ve sesleri kullandıkları yanıtını verdikleri görülmektedir (\%54). Örneğin, bir ebeveyn (E-15), ilgili soruya yanıt olarak çocuğunun kardeşi / kardeşlerine yönelttiği iletişim stilini tanımlarken "... işaret, elinden tutup göstererek..." yanıtı verirken, başka bir ebeveyn ise (E-1), “..elini tutar götürür.." yanıtı ile çocuğunun kardeşi / kardeşlerine yönelttiği iletişim stilini ifade ettiği belirlenmiştir. Ebeveynlerin, çocuklarının kardeşleri ile olan etkileşimlerinde, çocuklarının iletişim stillerini betimlemeye yönelik diğer verdikleri yanıtlara bakıldığında, çocuklarının kardeşleri ile tek sözcük ile (\% 32) veya cümle kullanarak sözel iletişim kurduğunu (\% 18) ifade etmişlerdir. Ebeveynlerin kendilerinden farklı olarak kardeşleri ile olan etkileşimlerinde artan oranda (\%10) çocuklarının iletişim becerilerinin yetersiz olduğunu ifade ederek, kardeşleri ile hiç iletişim kurmadığını belirtmişlerdir.

\section{Akranları ile İletişim Stilleri}

" Çocuğunuzun duygularını, düşüncelerini ve ihtiyaçların akranlarına nasıl ifade ettiğini anlatır mısınız?" sorusuna verilen yanttların analiz edilmesi sonucunda ortaya çıkan ebeveyn görüşleri Tablo $16^{\prime}$ da sunulmuştur. 
Otizmli Çocuğa Sahip Olan Ebeveynlerin Çocuklarının Günlük Yaşam Özellikleri, Günlük Oyun

Etkileșimleri, Problem Davranışlar ve İletișim Stillerine İlişkin Görüşleri

Tablo 16: Ebeveynlere Göre Çocuklarının Akranlarına Yönelik İletişim Stilleri

\begin{tabular}{lcc}
\hline \multicolumn{1}{c}{ Cevaplar } & $N$ & $\%$ \\
\hline İletişim yetersizliği & 22 & 44 \\
Tek sözcük ile iletişim kurma & 15 & 30 \\
Jest ve sesler ile iletişim kurma & 15 & 30 \\
Cümle kullanarak sözel iletişim kurma & 3 & 6 \\
Tanımlayamama & 2 & 4 \\
\hline
\end{tabular}

Tablo $16^{\prime}$ da, ebeveynlere göre çocuklarının akranlarına yönelttikleri dil ve iletişim özellikleri bakımından, ebeveynlerine ve kardeş / kardeşlerine yönelttikleri iletişim stilinden farklı olarak en sık olarak çocuklarının akranları ile olan etkileşimlerinde, iletişim yetersizliği yaşadıklarının bildirildiği görülmektedir (\% 44). Bununla birlikte, belirli sayıda ebeveynin ise çocuklarının akranları ile tek sözcük (\%30) veya jest ve sesler ile iletişim kurduğu yanıtını verdiği bulgulanmıştır (\% 30). Örneğin, bazı ebeveynler (E-6, E-13, E-36), ilgili soruya yanıt olarak çocuğunun akranlarına yönelttiği iletişim stilini tanımlarken "... başka çocuklar ile iletişimi yok..." yanıtlarını vermiştir. Ebeveynlerin, çocuklarının akranları ile olan etkileşimlerinde, çocuklarının iletişim stillerini betimlemeye yönelik diğer verdikleri yanıtlara bakıldığında, çocuklarının akranları ile cümle kullanarak sözel iletişim kurduğunu (\% 6) ifade etmişlerdir. Bunun yanı sıra iki ebeveyn ise çocuklarının akranları ile olan etkileşimlerinde kullandıkları iletişim stilini tanımlayamadıklarını belirtmiştir (\% 4).

\section{Tartışma}

$\mathrm{Bu}$ araştırmada, otizmli çocuğa sahip olan ebeveynlerin; çocuklarının yer aldığı günlük yaşam rutinlerine yönelik deneyimleri ile çocuklarının kendileri ile olan oyun etkileşimleri ve iletişim becerileri ile sergiledikleri var olan problem davranışlarına ilişkin görüşlerinin derinlemesine betimlenerek incelenmesi amaçlanmıştır. 


\section{Günlük Yaşam Özellikleri}

$\mathrm{Bu}$ araştırmada, katılımcı ebeveynler, normal gelişim gösteren çocuğa sahip olan ebeveynler ile kendilerini karşılaştırdıklarında, sıradan bir günlerine ilişkin yaşam özellikleri ile ilgili olarak görüşleri doğrultusunda, en sık verdikleri yanıttan başlayarak sırasıyla, tüm günlerini çocuklarına adadıkları, daha az dinlenme süresine sahip oldukları, günlük meşguliyetlerinin daha fazla olduğu, daha fazla stresli oldukları, üzüntülü ve kaygı duygu durumlarını daha yoğun yaşadıkları belirlenmiştir. Otizmli çocuğa sahip olan ebeveynlerin sosyal yaşam özelliklerini inceleyen ilgili araştırmalara bakıldığında, bu bulguları destekler nitelikte, günlük ve sosyal yaşamlarının tanı öncesi sürece göre değişime uğradığı, (Cavkaytar ve ark., 2008; Ludlow, Skelly ve Rohleder, 2011; Nealy ve ark., 2012), ebeveynlerin günlük yaşamlarının çoğunlukla çocuklarının etrafında şekillendiği (Hock, Tim ve Ramisch, 2011) günlük yaşamlarında normal gelişim gösteren çocuğa sahip olan ebeveynlere göre daha fazla sorumluk almaları gerektiği (Jarbrink, Fombonne ve Knapp, 2003) ve otizmli çocuğa sahip olan ebeveynlerin, normal gelişim gösteren çocuğa sahip olan ebeveynlere göre çocuklarında gözledikleri problem davranışlar (Abbeduto ve ark., 2004; Matherne, 2010) ve otizmden etkilenme düzeyleri (Ekas ve Whitman, 2010) ile ebeveynlerin bildirdikleri stres düzeyleri arasında ilişki olduğu (Gray, 2002) görülmektedir. Sonraki araştırmalarda, benzer araştırmalarda olduğu gibi (örn., Matherne, 2010) otizmli çocuğa sahip Türk ebeveynlerin günlük rutin özellikleri ile stres düzeyleri arasındaki ilişki incelenebilir. Bu bağlamda, bu araştırmanın öncesinde, beklentilerle uyumlu bir bulgu olarak, otizmli çocuğa sahip olan ebeveynlerin, ilgili bulgular doğrultusunda normal gelişim gösteren çocuğa sahip olan ebeveynlere göre otizmli çocuklarının günlük yaşamları üzerinde çeşitli açılardan (örn., stres düzeyi vb.) olumsuz etkilere sahip olduğunu bildirmeleri, benzer araştırmaların bulgularını destekler niteliktedir. Bunun yanı sıra, dikkat çekici bir bulgu olarak bu araştırmada, ebeveynlerin normal gelişim gösteren çocuğa sahip olan ebeveynlere göre daha gözlemci, kontrolcü ve dikkatli oldukların düşündükleri ortaya koyulmuştur. $\mathrm{Bu}$ bulgu ile ilişkili olarak, otizmli çocuklarda problem davranışlar ile stereo-tipik davranışların yoğun olarak gözlendiği bilinmektedir (Matson ve ark., 2009; Dominick ve ark., 2007). Dolayısıyla, bu araştırmada farklı bir tema altında incelenen ve ebeveynlerin çoğunluğunun çocuklarının sahip olduklarını bildirdikleri problem davranışlar ile stereo-tipik davranışların kendileri tarafından ev ortamında tanıklık edilmesi ve olası yıkıcı sonuçlarını önleme amaçlı olarak ifade ettikleri bu davranışların kendileri tarafından izlenmesinden kaynaklı olabilir. Bu doğrultuda, ileriki araştırmalarda, ebeveynlerin günlük yaşamdaki stres, kaygı, üzüntü düzeyi ve 
Otizmli Çocuğa Sahip Olan Ebeveynlerin Çocuklarının Günlük Yaşam Özellikleri, Günlük Oyun

Etkileşimleri, Problem Davranışlar ve İletişim Stillerine İlişkin Görüşleri 29 günlük rutin özellikleri ile çocuklarında gözledikleri problem davranışlar ilişkisel olarak incelenebilir.

\section{Günlük Oyun Etkileşimleri}

Ebeveynlerin çocukları ile günlük oyun etkileşimlerinin süresi ve niteliğine ilişkin görüşleri doğrultusunda elde edilen bulgulara bakıldığında ise, farklı sürelerde çocukları ile oyun etkileşimleri kurdukları görülmekle birlikte, ebeveynler arasında, çocukları ile günlük oyun etkileşim özellikleri süresi bakımından, en sık ifade edilen zaman aralığının 30-60 dakika olduğunu ifade etmelerine karşın, bu araştırma öncesinde beklenen bir bulgu olarak, çocuklarının kendileri ile günlük oyun etkileşimlerinin niteliği ile ilgili olarak, ebeveynlerin çoğunlukla çocuklarının kendileri ile olan oyun etkileşimlerinin süre ve nitelik olarak sinırl olduğunu düşündükleri ortaya koyulmuştur. Öte yandan otizmli çocukların tanı öncesi dönemden başlayarak (VanBerckelaer-Onnes, 2003) tanı sonrası dönemde oyun becerileri gelişiminde sınıllılıklara sahip olduğu (Charman, 1997; Mundy, Sigman ve Kasari, 1990; Ungerer ve Sigman, 1981) ve ebeveynleri ile olan etkileşimlerinde ortak katılımda yetersiz oldukları (Adamson, Bakeman, Deckner ve Nelson, 2012) bilinmesine karşın, bazı ebeveynlerin ise şaşırtıcı bir şekilde, çocuklarının kendileri ile olan oyun etkileşimlerinde, etkileşimi başlatma ve sürdürme yeterliliğine sahip olduklarmı bildirdikleri bulgulanmıştır. Bu doğrultuda, otizmli çocuğa sahip olan ebeveynlerin, çocuklarının kendileri olan oyun etkileşimlerine ilişkin görüşlerini inceleyen bir araştırmaya rastlanmamış olmakla birlikte, çocukların oyun davranışlarının niteliği üzerinde etkileri olduğu düşünülen ebeveyn ile ilişkilerinin niteliği açısından (Naber ve ark., 2008), otizmli çocukların ebeveynleri ile olan etkileşimlerini inceleyen betimsel araştırmalara bakıldığında, bu araştırmanın bulgularını destekler nitelikte, tekrarlayıcı bir bulgu elde edilmemesine karşın serbest oyun etkileşiminde otizmli çocukların, anne ve babalarına göre ailedeki diğer kardeşlerine yönelik daha fazla oyun etkileşimi başlatıcı davranışlar sergiledikleri bildirilmiştir (El-Ghoroury ve Romanzcyk, 1999). Bunun yanı sıra, ebeveynlerin otizmli çocukları ile etkileşim geliştirmeleri ve sürdürmelerinde sinırlılıklar gözlenmekle birlikte (Diken, 2012; Doussard-Roosevelt, Joe, Bazhenova ve Porges, 2003; Spiker, Boyce ve Boyce, 2002) otizmli çocukların ebeveynleri ile olan oyun etkileşimlerinde, oyun etkileşimini başlatma ve sürdürmede güçlük yaşadıkları da bilinmektedir (Adamson, McArthur, Markov, Dunbar ve Bakeman, 2001; Jackson ve ark., 2003). Ayrıca, otizmli çocuklarda normal gelişim gösteren çocuklara göre daha yoğun olarak gözlenen tekrarlayıcı davranışların (Bodfish, Symons, Parker ve Lewis, 2000) oyun becerileri ile ilişkili olduğu dikkate alındığında (Honey, Leekam, Turner ve McConachie, 2007), ebeveynlerin çoğunluğunun 
çocuklarının kendileri olan oyun etkileşimlerinin niteliğinin düşük olduğunu düşünmeleri, bu araştırmadaki diğer tema ile ilişkili olarak, hatırlanacağı gibi ebeveynlerin çoğunluğunun çocuklarının sahip olduğunu düşündükleri tekrarlayıcı davranışlar ile ilişkili olabilir. İleriki araştırmalarda, bu tür bir ilişkinin varlığı betimsel olarak incelenebileceği gibi, ebeveynlerin çocukları ile olan oyun etkileşimlerindeki etkileşimsel davranışlarına ilişkin görüşleri ile çocukları ve ebeveynlerin etkileşimsel davranışlarının betimsel olarak gözlenmesi yoluyla karşılaştırılarak incelenebilir. Ayrıca, ilgili bulguların, ebeveynlerin çocuklarının oyun etkileşimleri hakkında çoğunlukla alan yazınla tutarlı biçimde bilgiler sağladığını ortaya koyduğu dikkate alındığında, erken çocukluk özel eğitimi alanında çalışan uygulamacılar açısından müdahale programları geliştirilmesi öncesinde, ebeveyn görüşmelerinde oyun becerileri ile ilgili bilgiler elde edilmesinin gerekliliğinin yanı sıra hedef müdahale alanı olarak oyun becerilerinin göz önünde bulundurulmasının önemli olduğu düşünülmektedir.

\section{Problem Davranışlar/Tekrarlayıcı-Sınırlı İlgi Davranışları}

Daha önce değinildiği gibi duygu ve davranış problemleri (Gray ve ark., 2012) ile tekrarlayıcı ve sınırlı davranışların (Lewis ve Bodfish, 1998; Matson ve ark., 2009) otizmli çocuklar arasında yaygın olarak gözlendiği bilinmektedir. İlişkili olarak bu araştırmada, ebeveynlerin çocuklarında gözledikleri problem davranışlar ile tekrarlayıcı ve sınırlı ilgi alanları davranışlarına ilişkin görüşleri doğrultusunda, ebeveynlerin büyük çoğunluğunun çocuklarında problem davranışlar ile tekrarlayıcı ve sınırlı ilgi alanı davranışları gözledikleri; bu davranışlar arasında en sık olarak anlamsız ses çıkarma biçiminde tanımladıkları vokal tekrarlayıcı davranışlar, başkalarına vurma, ağlama ve öfke nöbetleri ile başkalarını ısırma ve nesneler ile ilişkili sınırlı ilgi alanı davranışları gözlediklerini bildirdikleri görülmüştür. Bunun yanı sıra, ebeveynlerin çoğunluğunun çocuklarında gözledikleri bu davranışların sıklıkla herhangi bir kişinin varllğg ve ortam fark etmeksizin veya ev ortamında çıktığını bildirdikleri ve bu davranışların çoğunlukla başkasının ilgisini elde etme amacına yönelik ortaya çıktığını düşündükleri araştırma bulguları arasındaki yerini almıştır. İlgili araştırmalara bakıldığında bu araştırmanın bulguların destekler nitelikte, otizmli çocuğa sahip olan ebeveynlerin çocuklarında problem davranışlar ile tekrarlayıcı davranışları gözlediklerini bildirdikleri görülmüştür (Keenan, Dillenburger, Doherty, Byrne ve Gallagher, 2010; Hall ve Graff, 2012; Ho ve ark., 2012; Tsai, Tsai ve Shyu, 2008). Bunun yanı sıra, önceki araştırma bulgularını (Ho ve ark., 2012) tekrarlayıcı biçimde ve tutarlı olarak, ebeveynler tarafından en sık bildirilen davranış problemlerinin başında fiziksel ve sözel öfke ile yıkıcı davranışların geldiği, bu davranışların diğer ortamlara göre ev ortamında daha yoğun ortaya çıktığı ve bu davranışlara 
Otizmli Çocuğa Sahip Olan Ebeveynlerin Çocuklarının Günlük Yaşam Özellikleri, Günlük Oyun

Etkileşimleri, Problem Davranışlar ve İletişim Stillerine İlişkin Görüşleri

yol açan davranış öncesi durumların başında ebeveynlerin çocuklarının istedikleri bir nesne veya etkinliğe ulaşma geldiğini bildirdikleri belirlenmiştir. Ayrıca ilgili araştırmada bu araştırmanın aksine, ebeveynlerin öfke davranışlarının hedefinin yoğun olarak kişilere yönelik olduğunu bildirdikleri rapor edilmiştir. Bu bağlamda, beklenen bir bulgu olarak otizmli çocuğa sahip olan ebeveynlerin çocuklarında davranış problemleri ile tekrarlayıcı ve yineleyici davranışları gözledikleri, bu davranışlar arasından en yoğun gözlenilen davranışların ise öfke davranışları ve dişa yönelimli problem davranışlar ile anlamsız ses çıkarma olarak tanımladıkları vokal tekrarlayıcı davranışlar sergiledikleri söylenebilir. Öte yandan, bu bulgular ile ilişkili olarak, bu araştırmada katılımcı grubunda bulunan ebeveynlerin çoğunlukla 912 yaş aralığında ( $\mathrm{f}=29)$ olan çocuğa sahip ebeveynler olduğu dikkate alındığında, bu araştırmanın bulguları ile tutarlı olarak, Ho ve arkadaşları (2012), ortalama olarak 9 yaş civarında olan otizmli çocuğa sahip olan ebeveynlerin, diğer yaş grubunda bulunan otizmli çocuğa sahip ebeveynlere göre anlamlı olarak daha sık bir şekilde öfke davranışları bildirdiklerini ve bu davranışların daha sık olarak ev ortamında ortaya çıktığını belirlemişlerdir. Bu doğrultuda, bu araştırmada ebeveynlerin otizmli çocukların yoğun olarak öfke davranışları sergilediklerini ve bu davranışların daha sık olarak ev ortamında ortaya çıktığını bildirmeleri; katılımcı grubun, bu yaşlar aralığında olan çocukların ebeveynlerinden oluşmasından kaynaklanabilir. İleriki araştırmalarda, otizmli çocuğa sahip olan Türk ebeveynlerin çocuklarında gözledikleri davranış problemleri ile tekrarlayıcı ve yineleyici davranışlara ilişkin görüşleri yaş değişkeni ile ilişkili olarak incelenebilir. Ayrıca, otizmli çocuğa sahip olan ebeveynlerin çocuklarında gözledikleri problem davranışlar ile tekrarlayıcı ve yineleyici davranışlara ilişkin görüşleri çocukların sahip olduğu otistik davranışların dereceleri ile ilişki olarak incelenebilir. Bununla birlikte, ebeveynlerin bu davranışlara ilişkin görüşlerinin çocukları ile olan etkileşimsel stilleri üzerindeki olası etkileri de araştırılabilir.

$\mathrm{Bu}$ araştırmada elde edilen diğer bulgular ise, çocuklarının problem davranış sergileme durumlarında farklı biçimlerde olmakla birlikte, ebeveynlerin sıklıkla çocuklarını davranışları nedeniyle sözel olarak uyardıkları, çocuklarını bulundukları ortamdan dışarı çıkardıkları, davranışlarını görmezden geldikleri, çocuklarının dikkatlerini başka bir nesne veya olaya yöneltme girişiminde bulundukları veya çocukları ile fiziksel olarak duygusal temas kurduklarını bildirmeleri olmuştur. $\mathrm{Bu}$ araştırmanın bulguları ile tutarlı olarak bir araştırmada (Tsai ve ark., 2008) ebeveynlerin çocuklarının uygun olmayan davranış sergilemeleri durumunda çocuklarını sözel olarak uyardıkları belirlenmiştir. Bunun yanı sıra, çocuklarının aşırı düzeyde hırçınlaşmaları veya öfkelenmeleri durumunda ebeveynlerin sıklıkla sarılma, kucağa alma veya 
durdurma gibi çocukları ile fiziksel olarak duygusal temas kurdukları bildirmeleri bu araştırmanın dikkat çekici bulguları arasında yerini almaktadır. Buna karşın, ilgili araştırmalarda, bu araştırmada ortaya çıkan bulguların aksine, ebeveynlerin çocuklarının öfkelenmeleri durumunda çoğunlukla olumsuz duygular yaşadıklarını ifade ederek (Tsai ve ark., 2008; Ho ve ark., 2012) sakındıkları, etkileşimlerini sinırlandırdıkları, çatışma durumuna geldikleri veya bu araştırmanın bulguları ile tutarlı olarak fiziksel temas kurmadan sakinleştirmeye çalıştıklarını bildirdikleri bulgulanmışır (Ho ve ark., 2012). Bu araştırma ile ilişkili olarak benzer araştırmaların sayısının sınırlı olduğu görülmekle birlikte, otizmli çocuklarda gözlenen davranış problemlerinin ebeveynlerin stres düzeyi ile ilişkili olduğu (Abbeduto ve ark., 2004) ve artan stres düzeyinin ise ebeveyn ile çocuk etkileşimini olumsuz etkilediği (Osborne ve Reed, 2010) düşünüldüğünde, bu araştırmada Türk ebeveynlerin, otizmli çocuklarının aşırı düzeyde öfke davranışları sergilemeleri durumunda sarılma gibi fiziksel olarak duygusal temas kurdukların bildirmeleri, dikkat çekici biçimde kültürel olarak otizmli çocuğa sahip Türk ebeveynlerin çocuklarında gözledikleri problem davranışlar karşısında tepkide bulunma stillerine ilişkin bilgi sağlamaktadır. Öte yandan, ilgili nitel bir araştırmada Özen ve arkadaşları (2002) zihinsel yetersizliği olan çocuğa sahip Türk ebeveynlerin bu araştırmada da benzer olarak bildirdikleri çocuklarında gözledikleri problem davranışlara yönelik (örn., başkasına zarar verme, nesne fırlatma vb.) tepkileri arasında sözel olarak uyarıda bulunma olduğu yanı sıra fiziksel olarak ceza uyguladıklarını da bildirmişlerdir. Bu araştırma öncesinde beklenen bulgular arasında olmasına karşın, ebeveynlerin anlamlı bir çoğunluğunun fiziksel ceza uyguladıkları yönünde bir görüş bildirmemeleri ayrıca dikkat çekicidir. Dolayısıyla, otizmli çocuğa sahip Türk ebeveynlerin, çocuklarında gözlediklerini bildirdikleri problem davranışların yanı sıra öfke davranışları karşısında sıklıkla sözel olarak uyarıda bulundukları söylenebilir. $\mathrm{Bu}$ bulgunun daha geniş örneklem grubu üzerinde problem davranışların öncesi, sırası ve sonrasına ilişkin derinlemesine bilgi elde etmeyi amaçlayan nitel araştırmalar ile desteklenilmesine gereksinim duyulmaktadır. Bunun yanı sıra, ebeveynlerin çocuklarında gözledikleri problem davranışların azaltılması veya yok edilmesine ilişkin beklentileri incelenebilir. Bu bağlamda, tüm bu bulgular ile ilişkili olarak, otizmli çocuklar ve ebeveynleri ile çalışan uygulamacıların, otizmli çocuklarda gözlenen davranış problemlerine yönelik müdahale planları geliştirilmesi sürecinde alternatif müdahale yöntemi olarak ebeveyn merkezli ve çoklu disipline dayalı müdahale yaklaşımlarını benimsemelerinin önemli olduğu düşünülmesinin yanı sıra, problem davranışarla başa çıkma yollarına ilişkin ebeveynlere rehberlik etmeye yönelik müdahale planları geliştirmelerinin gerekli olduğu da önerilmektedir. 
Otizmli Çocuğa Sahip Olan Ebeveynlerin Çocuklarının Günlük Yaşam Özellikleri, Günlük Oyun

Etkileşimleri, Problem Davranışlar ve İletişim Stillerine İlişkin Görüşleri

\section{İletişim Stilleri}

Otizmin ayırt edici tanı ölçütlerinden birinin dil ve iletişim alanında yaşanılan yetersizlikler olduğu bilinmektedir (Amerikan Psikiyatri Birliği, 2000). Bu araştırmanın son bölümünde ise ebeveynlerin çocuklarının kendilerine, kardeşlerine ve akranlarına yönelttikleri dil ve iletişim stillerine ilişkin görüşleri incelenmiştir. Bu doğrultuda elde edilen dikkat çekici bulgulardan biri, ebeveynler arasında anlamlı bir çoğunluğun, dil ve iletişim özellikleri bakımından, kendileri ve kardeşleri ile iletişim kurarken yoğun olarak jest ve sesleri kullandıklarını bildirmeleri olmuştur. Bazı ebeveynlerin çocuklarının kendileri ile olan iletişimlerinde sözcük veya cümle kurduğunu bildirmelerine rağmen, ebeveynler arasında en sık olarak çocuklarının kendileri ile olan iletişimlerinde yoğun olarak jest ve sesler kullandıkları bildirmeleri, çocuklarının gelişimsel olarak dil öncesi iletişim döneminde bulunmasından kaynaklı olabileceği düşünülmektedir. Bu araştırmada 2 ile 12 yaş gibi geniş bir yaş aralığında bulunan çocukların ebeveynleri yer almasına rağmen araştırma öncesinde çocukların dil ve iletişim gelişim düzeyleri kontrol altına alınarak ebeveynlerin görüşlerinin incelenmesi amaçlanmaması nedeniyle, çocuklarının iletişim gelişimleri ile ebeveynlerin görüşleri arasındaki olası bir ilişkinin incelenememesi bu araştırmanın bir sınırlılığı olarak düşünülebilir. İlerleyen araştırmalarda, otizmli çocukların dil ve iletişim becerileri gelişimi düzeyleri ile ebeveynlerin çocuklarının iletişim becerilerine ilişkin görüşleri arasındaki ilişki karşılaştırılarak incelenebilir. Ayrıca, ilgili bir araştırmada olduğu gibi (örn., Brady, Skinner, Roberts ve Hennon, 2006) sonraki araştırmalar açısından ebeveynlerin, çocuklarının iletişim becerilerine ilişkin görüşleri ve beklentilerinin yanı sıra, ebeveynlerin görüşleri ve beklentileri çocukların sahip olduğu dil ve iletişim becerileri gelişimi düzeylerine göre karşılaştırılarak incelenmesi önerilmektedir. Nitel bir araştırmada, Brady ve arkadaşları (2006), fragile $X$ sendromlu çocuğa sahip ebeveynlerin çocuklarının yaşadığı iletişim yetersizliğinin çocuklarının ne istediğini anlayamama güçlüğü ile ilişkili olduğunu belirleyerek, bu bilginin otizmli çocuğa sahip ebeveynler açısından da ortak bir bilgi olabileceğini önermişlerdir. Bu bilgiye ek olarak, korelasyonel araştırmaların, ebeveynlerin sözel yanıtlayıcılık düzeyleri ile otizmli çocukların dil becerileri arasında güçlü bir ilişki olduğunu ortaya koyduğu (Venker, Mcduffie, Weismer ve Abbeduto, 2011) ve ebeveynlerin etkileşim stillerinin ve sıklığının, otizmli çocukların dil gelişimleri üzerinde etkileri olduğu (Siller ve Sigman, 2002) dikkate alındığında, uygulamacılar açısından otizmli çocukların özellikle dil öncesi iletişim becerilerinin yanı sıra dilin tüm bileşenlerinin desteklenilmesine yönelik ebeveyn merkezli müdahale programlarının geliştirilmesinin ve uygulanmasının önemli olduğu düşünülmektedir. İlgili tema altında dikkat çekici bulgular arasında yer alan ve en sık bildirilen diğer 
ebeveyn görüşü ise kendileri ve kardeşlerine göre çocuklarının en sık olarak akranları ile olan etkileşimlerinde iletişim yetersizliği sergilediklerini bildirmeleri olmuştur. Bu tema ile ilişkili ebeveyn görüşlerinin nitel olarak incelendiği araştırmaların sayısı oldukça sınırlı olmakla birlikte, bu bulguyu kısmen destekler nitelikte, ilgili nitel bir araştırmada Hoppe (2005) otizmli çocuğa sahip ebeveynlerin, çocuklarının yakın çevresinde bulunan diğerleri ile iletişimlerinin yetersiz olduğunu bildirdiklerini belirtmiştir. Öte yandan beklenen bir bulgu özelliği taşıyan bu bulgu ile ilişkili olarak, otizmli çocukların akranları ile sosyal etkileşim kurma güçlükleri yaşadığının bilinmesinin yanı sira (Boyd, Conroy, Asmus ve McKenney, 2011); bir sinırlılık olarak bu araştırmada yer alan ebeveynlerin çocuklarının çoğunlukla ayrıştırılmış eğitim ortamlarını içeren bağımsız otistik çocuklar eğitim merkezlerine devam eden çocuklar olduğu ve çocuklarının sıklıkla benzer yaştaki akranları ile okul ortamı dışında aile ziyaretlerinde gerçekleşen oyun etkileşimi bağlamında bir araya geldikleri dikkate alındığında, otizmli çocukların sınırlı ve yineleyici oyun davranışlarına sahip olması (Hannah, 2001; Bruckner ve Yoder, 2007) ve olası bir şekilde ebeveynlerin çocuklarının akranları ile sınırlı etkileşimlerine tanıklık etmiş olmalarının, ebeveynlerin çocuklarının akranları ile iletişim yetersizliği yaşadığını düşünmeleri üzerinde etkileri olabilir. Bu doğrultuda, ilerleyen araştırmalarda örneklem grubu olarak kaynaştırma ortamlarında eğitim alan otizmli çocukların akranları ile olan etkileşimlerinde kullandıkları iletişim becerilerine ilişkin ebeveyn görüşleri derinlemesine incelenebilir. Bunun yanı sıra, erken çocukluk dönemi ve okul öncesi dönemde bulunan otizmli Türk çocukların sosyal etkileşim ve iletişim becerilerinin desteklenmesine yönelik akran temelli öğretim modellerinin geliştirilmesinin ve yaygınlaştırılmasının gerekli olduğu düşünülmektedir. 
Otizmli Çocuğa Sahip Olan Ebeveynlerin Çocuklarının Günlük Yaşam Özellikleri, Günlük Oyun

Etkileşimleri, Problem Davranışlar ve İletişim Stillerine İlişkin Görüşleri

\section{Kaynakça}

Abbeduto, L., Seltzer, M.M., Shattuck, P., Krauss, M.W., Orsmond, G., Murphy, M.M. (2004). Psychological well-being and coping in mothers of youths with autism, down syndrome, or fragile $\mathrm{X}$ syndrome. American Journal on Mental Retardation, 109(3), 237-254.

Adamson, L.B., McArthur, D., Markov,Y., Dunbar, B. ve Bakeman, R. (2001). Autism and joint attention:Young children's responses to maternal bids. Journal of Applied Developmental Psychology, 22, 439-453.

Adamson, L.B., Bakeman, R., Deckner, D.F. ve Nelson, P.B. (2012). Rating parent-child interactions: Joint engagement, communication dynamics, and shared topics in autism, down syndrome, and typical development. Journal of Autism and Developmental Disorders, 42(12), 2622-2635.

Alqahtani, M.M.J. (2012). Understanding autism in Saudi Arabia: A qualitative analysis of the community and cultural context. Journal of Pediatric Neurology, 10, 15-22.

Amerikan Psikiyatri Birliği. (2001). Psikiyatride hastalıkların tanımlanması ve sınıflandırılması el kitabı (Çev. Köroğlu E.) (4. Baskı). (DSM-IV-TR). Hekimler Yayın Birliği, Ankara, 2001. (Özgün çalışma, 2000)

Beuker, K.T., Schjølberg, S., Lie, K.K., Donders, R., Lappenschaar, M., Swinkels, S.H. ve Buitelaar, J.K. (2013). The structure of autism spectrum disorder symptoms in the general population at 18 months. Journal of Autism and Developmental Disorders, 43, 45-56.

Bodfish, J.W., Symons, F.J., Parker, D.E. ve Lewis, M.H. (2000). Varieties of repetitive behavior in autism: Comparisons to mental retardation. Journal of Autism and Developmental Disorders, 30, 237-243.

Boyd, B.A. (2002). Examining the relationship between stress and lack of social support in mothers of children with autism. Focus on Autism and Other Developmental Disabilities, 17(4), 207-215.

Boyd B.A., Conroy, M.A., Asmus, J.M. ve McKenney, E.L.W. (2011). Direct observation of peer-related social interaction: Outcomes for young children with autism spectrum disorders. Exceptionality, 19 (2), 94108.

Brewin, B. J., Renwick, R. ve Schormans, A. F. (2008). Parental perspectives of the quality of life in school environments for children with asperger syndrome. Focus on Autism and Other Developmental Disabilities, 23(4), 242-252.

Brady, N., Skinner, D., Roberts, J. ve Hennon, E. A. (2006). Communication in young children with fragile $X$ syndrome: A qualitative study of 
mothers' perspectives. American Journal of Speech Language Pathology, 15, 353-364.

Brobst, J., Clopton, J., Hendrick, S., (2009). Parenting children with autism's spectrum disorders: The couple's relationship. Focus on Autism and Other Developmental Disabilities, 24, 38-49.

Bruckner, C.T. ve Yoder, P. (2007). Restricted object use in young children with autism: Definition and construct validity. Autism, 11, 161-171.

Cavkaytar, A., Batu, S. ve Çetin-Beklan, O. (2008). Perspectives of Turkish mothers on having a child with developmental disorders. International Journal of Special Education, 23, 101-109.

Charman, T. (1997). The relationship between the joint attention and pretend play deficit in autism. Development and Psychopathology, 9, 1-16.

Conti-Ramsden, G., Botting, N. ve Durkin, K. (2008). Parental perspectives during the transition to adulthood of adolescents with a history of specific language impairment (SLI). Journal of Speech, Language and Hearing Research, 51, 84-96.

Daniels, J.L., Forssen., U., Hultman, C.M., Cnattingius, S., Savitz, D.A., Feychting, M. ve Sparen P. (2008). Parental psychiatric disorders associated with autism spectrum disorders in the offspring. Pediatrics, 5, 1357-1362.

Diken, I. H. (2012). Türk annelerinin ve özel gereksinimli çocuklarının etkileşimsel davranışlarının araştırılması: Erken müdahaleye yönelik öneriler (An exploration of interactional behaviors of Turkish mothers and their children with special needs: Implications for early intervention practices). Eğitim ve Bilim, 37, 163.

Dominick, K.C., Davis, N.O., Lainhart, J., Tager-Flusberg, H. ve Folstein, S. (2007). Atypical behaviors in children with autism and children with a history of language impairments. Research in Developmental Disabilities, 28, 145-162.

Doussard-Roosevelt, J.A., Joe, C.M., Bazhenova, O.V. ve Porges, S.W. (2003). Mother-child interaction in autistic and nonautistic children: Characteristics of maternal approach behaviours and child social responses. Development and Psychopathology, 15, 277-295.

El-Ghoroury, N.H. ve Romanczyk, R.G. (1999). Play interactions of family members towards children with autism. Journal of Autism and Developmental Disabilities, 29(3), 249-258.

Ekas, N. V. ve Whitman, T. L. (2010). Autism symptom topography and maternal socioemotional functioning. American Journal of Intellectual and Developmental Disabilities, 115, 234-249. 
Otizmli Çocuğa Sahip Olan Ebeveynlerin Çocuklarının Günlük Yaşam Özellikleri, Günlük Oyun

Etkileşimleri, Problem Davranışlar ve İletişim Stillerine İlişkin Görüşleri 37

Gold, N. (1993). Depression and social adjustment in siblings of boys with autism. Journal of Autism and Developmental Disorders, 23, 147-163.

Gray, D.E. (2002). Ten years on: A longitudinal study of families of children with autism. Journal of Intellectual and Developmental Disability, 27(3), 215-222.

Gray, K., Caroline, K., Taffe, J., Brereton, A., Stewart., E. ve Bruce, T. (2012). Trajectory of behavior and emotional problems in autism. American Journal on Intellectual and Developmental Disabilities, 117(2), 121-133.

Hall, H.R. ve Graff, J.C. (2012). Maladaptive behaviors of children with autism: Parent support, stress, and coping. Issues in Comprehensive Pediatric Nursing, 35(3-4), 194-214.

Hannah, L. (2001). Teaching young children with autism spectrum disorders to learn: A practical guide for parents and staff in general education classrooms and preschools. Shawnee Mission, KS: Autism Asperger Publishing Company.

Hastings, R.P. (2003). Behavioral adjustment of siblings of children with autism. Journal of Autism and Developmental Disorders, 33, 99-104.

Hastings, R.P. ve Brown, T. (2002). Behavior problems of autistic children, parental self-efficacy and mental health. American Journal on Mental Retardation 107, 222-232.

Hebert, E.B. ve Koulouglioti, C. (2010). Parental beliefs about cause and course of their child's autism and outcomes of their beliefs. Issues in Comprehensive Pediatric Nursing, 33, 149-163.

Hines, M., Balandin, S. ve Togher, L. (2012). Buried by autism: Older parents' perceptions of autism. Autism, 16, 15-26.

Ho, B.P.V., Stephenson, J. ve Carter, M. (2012). Anger in children with autism spectrum disorder: Parent's Perspectives. International Journal of Special Education, 27, 14-32.

Hock, R.M., Timm, T.M. ve Ramisch, J.L. (2011). Parenting children with autism spectrum disorders: A crucible for couple relationships. Child $\mathcal{E}$ Family Social Work, 17, 406-415.

Hodapp, R.M. (1999). Indirect effects of genetic mental retardation disorders: Theoretical and methodological issues. International Review of Research in Mental Retardation, 22, 27-50.

Honey, E., Leekam, S., Turner, M. ve McConachie, H. (2007). Repetitive behaviour and play in typically developing children and children with autism spectrum disorders. Journal of Autism and Developmental Disorders, 37, 1107-1115.

Hoppe, S.E.(2005). Parent Perceptions: Communication, Interaction, and Behavior in Autism. Teaching Exceptional Children Plus, 1, 14-25. 
Jackson, C.T., Fein, D.,Wolf, J., Jones, G., Hauck, M.,Waterhouse, L. ve Feinstein, C. (2003). Responses and Sustained Interactions in Children with Mental Retardation and Autism. Journal of Autism and Developmental Disorders, 33, 115-121.

Jarbrink, K., Fombonne, E. ve Knapp, M. (2003). Measuring the parental, service and cost impacts of children with autistic spectrum disorder: A pilot study. Journal of Autism and Developmental Disorders, 33(4), 395-402.

Kasari, C. ve Sigman, M. (1997). Linking Parental Perceptions to Interactions in Young Children with Autism. Journal of Autism and Developmental Disorders, 27, 39-57.

Keenan, M., Dillenburger, K., Doherty, A., Byrne, T. ve Gallagher, S. (2010). The experiences of parents during diagnosis and forward planning for children with autism spectrum disorder. Journal of Applied Research in Intellectual Disabilities, 23(4), 390-397.

Landa, R. (2007). Early Communication Development and Intervention for Children with Autism. Mental Retardation and Developmental Disabilities Research Reviews, 13, 16-25.

Leach, D. ve La Rocque, M. (2011). Increasing Social Reciprocity in Young Children with Autism. Intervention in School and Clinic, 46, 150-156.

Lee, L., Harrington, R. A. ve Louie, B. B. ve Newschaffer, C. J. (2008). Children with autism: Quality of life and parental concerns. Journal of Autism and Developmental Disorders, 38(6), 1147-1160.

Lewis, M.H. ve Bodfish, J.W. (1998). Repetitive behavior disorders in autism. Mental Retardation and Developmental Disabilities Research Reviews, 4, 80-89.

Ludlow, A., Skelly, C. ve Rohleder P. (2012). Challenges faced by parents of children

diagnosed with autism spectrum disorder Journal of Health Psychology 17(5):

702- 711..

Matherne, M. (2010). Daily routine, parental stress and behavior problems of children with autism (Yayımlanmamış yüksek lisans tezi). Southeastern Louisiana University.

Matson, J.L., Dempsey, T. ve Fodstad, J.C. (2009). Stereotypies and repetitive/restrictive behaviors in infants with autism and pervasive developmental disorder. Developmental Neurorehabilitation, 12, 122-127.

Meirsschauts, M., Roeyers, H. ve Warreyn, P. (2011). The social interactive behaviour of young children with autism spectrum disorder and their mothers. Autism, 15, 43-64. 
Otizmli Çocuğa Sahip Olan Ebeveynlerin Çocuklarının Günlük Yaşam Özellikleri, Günlük Oyun

Etkileşimleri, Problem Davranışlar ve İletişim Stillerine İlişkin Görüşleri

Meral, B.F. ve Cavkaytar, A. (2012). A Study on Social Support Perception of Parents who Have Children with Autism. International Journal on New Trends in Education and Their Implications, 3, 124-135.

Mercer, L., Creighton, S., Holden, J.J.A. ve Lewis, M.E.S. (2006). Parental perspectives on the causes of an autism spectrum disorder in their children. Journal of Genetic Counseling, 15, 41-50.

Miniscalco, C.; Franberg, J.; Schachinger-Lorentzon, U.; Gillberg, C. (2012). Meaning what you say? Comprehension and word production skills in young children with autism. Research in Autism Spectrum Disorders, 6, 204-211.

Mundy, P., Sigman, M. ve Kasari, C. (1990). A longitudinal study of joint attention and language development in autistic children. Journal of Autism and Developmental Disorders, 20, 115-128.

Mundy, P. ve Burnette, C. (2005). Joint attention and neurodevelopmental models of autism. İçinde F. R. Volkmar, R. Paul, A. Klin ve D. Cohen (Ed.), Handbook of autism and pervasive developmental disorders, Vol. 1: Diagnosis, development, neurobiology, and behavior.(25th ed., pp.1-32). Hoboken, NJ: John Wiley \& Sons.

Naber, F.B.A., Bakermans - Kranenburg, M.J., IJzendoorn, M.H. van, Swinkels, S.H.N., Buitelaar, J.K., Dietz, C., Daalen, E. Van, Engeland, H. van (2008). Play behavior and attachment in toddlers with autism. Journal of Autism and Developmental Disorders, 38, 857-866.

Nealy, C. E., O'Hare, L., Powers, J. D. ve Swick, D. C. (2012). The impact of autism spectrum disorders on the family: A qualitative study of mothers' perspectives. Journal of Family Social Work, 15, 187-201.

Osborne, L.A. ve Reed, P. (2010). Stress and self-perceived parenting behaviors of parents of children with autistic spectrum conditions. Research in Autism Spectrum Disorders, 4, 405-414.

Osterling, J., Dawson, G. (1994). Early recognition of children with autism: A study of first birthday home videotapes. Journal of Autism and Developmental Disorders, 24, 247-257.

Özen, A., Çolak, A. ve Acar, Ç. (2002). Zihin özürlü çocuğa sahip annelerin günlük yaşamda karşılaştıkları problem davranışlarla ilgili görüşleri. Özel Eğitim Dergisi, 3(2), 1-13.

Patterson, S., Smith, V. ve Jelen, M. (2009). Intervention practices for repetitive and stereotypic behaviour in individuals with autism spectrum disorder: A systematic review. Biennial Meeting of Society for Research in Child Development, Denver, Colorado, USA.

Rao, P. A. ve Beidel, D. C. (2009). The impact of children with highfunctioning autism on parental stress, sibling adjustment, and family functioning. Behavior Modifications, 33(4), 437-451. 
Rodger, S., Braithwaite, M. ve Keen, D. (2004). Early intervention for children with autism: Parental priorities. Australian Journal of Early Childhood, 29, 34-41.

Romski, M., Sevcik, R. A., Adamson, L.B., Smith, A., Cheslock, M. ve Bakeman, R. (2011). Parent perceptions of the language development of toddlers with developmental delays before and after participation in parent-coached langauge interventions. American Journal of Speech Language Pathology, 20, 111-118.

Roos, M, E., Mcduffie, S.A., Weismer, E.S., Gerhsbacher, A.M. (2008). A comparison of contexts for assesing joint attention in toddlers on the autism spectrum. Autism: The International Journal of Research and Practice, 12, 275-291.

Ross, P. ve Cuskelly, M. (2006). Adjustment sibling problems and coping strategies of brothers and sisters of children with autistic spectrum disorders. Journal of Intellectual \& Developmental Disability, 31, 7786.

Russell, G. ve Norwich, B. (2012). Dilemmas, diagnosis and de-stigmatization: Parental perspectives on the diagnosis of autism spectrum disorders. Clinical Child Psychology and Psychiatry, 17, 229-245.

Shaked, M. ve Yoram, B. (2006). Grappling with affliction: Autism in the Jewish Ultra Orthodox community in Israel. Culture, Medicine and Psychiatry, 30, 1-27.

Siller, M. ve Sigman, M. (2002). The behaviors of parents of children with autism predict the subsequent development of their children's communication. Journal of Autism and Developmental Disorders, 32, 77-89.

Skinner, D., Correa, V., Skinner, M. ve Bailey, D. (2001). Role of religion in the lives of Latino families of young children with developmental delays. American Journal of Mental Retardation, 106, 297-313.

Smith, I. M. ve Bryson, S. E. (1994). Imitation and action in autism: A critical review. Psychological Bulletin, 2, 259-273.

Spiker, D., Boyce, G.C. ve Boyce, L. K. (2002). Parent-child interactions when young children have disabilities. International Review of Research in Mental Retardation, 25, 35-70.

Steyaert, J.G ve De la Marche, W. (2008). What's new in autism?. European Journal of Pediatrics, 167(10), 1091-101.

Stoner, J.B., Jones Bock, S., Thompson, J.R., Angell, M.E., Heyl, B.S. and Browley, E.P. (2005). Welcome to our world: Parent perceptions of interactions between parents of young children with ASD and education professionals. Focus on Autism and Other Developmental Disabilities, 20(1), 39-51. 
Otizmli Çocuğa Sahip Olan Ebeveynlerin Çocuklarının Günlük Yaşam Özellikleri, Günlük Oyun

Etkileşimleri, Problem Davranışlar ve İletişim Stillerine İlişkin Görüşleri

Szatmari, P., Bryson, S.E., Boyle, M.H., Streiner, D.L. ve Duku, E. (2003). Predictors of outcome among high funtioning children with autism and Asperger syndrome. Journal of Child Psychology and Psychiatry, 44(4), 520-528.

Tsai, W., Tsai, J., Shyu, Y.L. (2008). Integrating the nurturer-trainer roles: Parental and behavior/symptom management processes for mothers of children with autism. Social Science and Medicine. 67(11), 798-1806.

Turnbull, A.P. ve Ruef, M. (1997). Family perspectives on inclusive lifestyle issues for people with problem behavior. Exceptional Children, 63, 211-227.

Turnbull, A., Turnbull, R. ve Wehmeyer, M.L. (2007). Exceptional lives. Special education in today's schools (5.Baskı). Upper Saddle River, NJ: Merrill/Prentice Hall.

Turner M. A. (1999). Repetitive behavior in autism: A review of psychological research. Journal of Child Psychology and Psychiatry, 40, 839-849.

Ungerer, J.A. ve Sigman, M. (1981). Symbolic play and language comprehension in autistic children. Journal of the American Academy of Child Psychiatry, 20,318-37.

Van Berckelaer-Onnes, I. A. (2003). Promoting early play. Autism, 7(4), 415-423.

Venker, C., McDuffie, A., Ellis Weismer, S. ve Abbeduto, L. (2011). Increasing verbal responsiveness in parents of children with autism: A pilot study. Autism, 16(6), 568-585.

Williams, P.G., Sears, L.L. ve Allard, A. (2004). Sleep problems in children with autism. Journal of Sleep Research, 13, 265-268.

Wilke, A.E., Tarbox, J., Dixon, D.R., Kenzer, A.L., Bishop, M.R. ve Kakavand, H. (2012). Indirect functional assessment of stereotypy in children with autism spectrum disorders. Research in Autism Spectrum Disorders, 6, 824-828.

Zwaigenbaum, L., Bryson, S., Rogers, T., Roberts, W., Brian, J. ve Szatmari, P. (2005). Behavioral manifestations of autism in the first year of life. International Journal of Developmental Neuroscience, 23, 143-155. 